\title{
Measuring the experience of remote home workers: A scoping review
}

Stefano Federici ${ }^{1}$, Maria Laura De Filippis ${ }^{1 *}$, Maria Laura Mele ${ }^{1}$, Simone Borsci ${ }^{2,3}$, Marco Bracalenti $^{1}$, Giovanni Bifolchi ${ }^{1}$, Giancarlo Gaudino ${ }^{4}$, Massimo Amendola $^{4}$, Antonello Cocco ${ }^{4}$, Emilio Simonetti ${ }^{5}$

${ }^{1}$ Department of Philosophy, Social and Human Sciences and Education, University of Perugia, Perugia, Italy

${ }^{2}$ Department Learning, Data analysis, and Technology, Cognition, Data and Education CODE group, Faculty of Behavioural, Management and Social Sciences, University of Twente, Enschede, the Netherlands

${ }^{3}$ Department of Surgery and Cancer, Faculty of Medicine, NIHR London IVD, Imperial College, London, United Kingdom

${ }^{4}$ DGTCSI-ISCTI, Directorate General for Management and Information and Communications Technology, Superior Institute of Communication and Information Technologies, Ministry of Economic Development, Rome, Italy

${ }^{5}$ Department of Public Service, Prime Minister's Office, Rome, Italy

\section{Author Note}

Stefano Federici (D) https://orcid.org/0000-0001-5681-0633

Marial Laura De Filippis (D) https://orcid.org/0000-0003-3282-3514

Maria Laura Mele (D) https://orcid.org/0000-0002-2714-4683

Simone Borsci (iD) https://orcid.org/0000-0002-3591-3577 
Marco Bracalenti (D) https://orcid.org/0000-0002-8768-3793

We have no known conflicts of interest to disclose. The present work was supported by Directorate General for Management and Information and Communications, Ministry of Economic Development (DGTCSI-ISCTI), and the Department of Public Service, Prime Minister's Office within the research project “Job-satisfying” on April 6, 2021.

Correspondence regarding this article can be addressed to Maria Laura De Filippis by email at: marialaura.defilippis@gmail.com 


\begin{abstract}
Introduction: Working from home (WFH) remotely is a modality of working that requires the careful design of systems of rules and tools to enable people to exchange information and perform actions. WFH is expected to expand after the COVID-19 pandemic, and how best to reliably assess and compare the experience of workers with different (sociotechnical) systems of WFH is central to the diffusion of acceptable modalities of remote working. However, the concept of experience and how it can be measured in the domain in WFH is yet to be clearly characterized.
\end{abstract}

Methods: Following the Preferred Reporting Items for Systematic Reviews and Meta-Analyses (PRISMA) methodology for scoping reviews, we systematically map the approaches used by researchers to assess WFH, identify which aspects are usually investigated, and examine how such aspects are usually measured in terms of questions and tools. Literature is collected using Scopus and Web of Science.

Results: Thirty-four records out of 323 focusing either on validating a scale, presenting theoretically the experience of workers or testing this empirically are included in the qualitative synthesis. The results highlight a lack of unified terminology and tools, with assessments of workers' experience mainly characterized by survey approaches and qualitative questions.

Conclusion: Clustering together the most investigated aspects in the literature and reviewing how these aspects are assessed, we propose a list of 10 relevant overarching dimensions and attempt to define workers' experience in the domain of WFH remotely. This definition can be used as a tool by researchers aiming to assess the experience of workers in order to inform the design or redesign of the sociotechnical systems that enable WFH.

Keywords: experience, satisfaction, workers' experience, working from home, remote working, assessment 


\section{Introduction}

Advancements in technologies and connectivity since the late 1990s have enabled the diffusion of distributed modalities of working outside the office (Bloom et al., 2015; Tagliaro \& Ciaramella, 2016). Researchers refer to the same distributed modalities of working with different names (Bolisani, 2020) e.g., teleworking, smart working, long-distance working, remote working at home, and working outside of the office. In this article, we focus only on working situations in which employees work outside of the office via a form of technology in their own adaptable space; therefore, we use the term "working from home" (WFH) to cover a wide range of remote working modalities.

WFH practices are regarded by companies as ways of reducing employees' workloads, through giving them the possibility to work (with formal and informal arrangements) a certain amount of time outside of their typical work facility (Davidescu et al., 2020). They are also seen as a strategic approach whereby companies can reduce the costs associated with their physical infrastructure (Angelici \& Profeta, 2020; Mazzucchelli, 2017; Tagliaro \& Ciaramella, 2016). The practice of WFH was quite consolidated, but only moderately diffused, before the COVID19 pandemic. For instance, data regarding job conditions in the 27 countries of the European Union in early 2020 suggested that on average, only $12 \%$ of employees were already used to this modality of working (EUROSTAT, 2021). Some researchers (Barrero et al., 2021; Bloom et al., 2015) have suggested that this low diffusion of WFH is mainly owed to a stigma of shirking associated with this modality of working, whereby remote workers were perceived as less controllable in terms of their performance compared to onsite employees. Empirical data reviews have also suggested that remote workers are less likely to be promoted compared to onsite workers, and that remote working positions are less desirable to productive workers (Bloom et al., 2015; Harrington \& Emanuel, 2020). Researchers agree that WFH options should be better designed so that this work modality can become more desirable to highly productive 
workers, maximizing the benefit to companies and the workforce alike (Bloom et al., 2015; Harrington \& Emanuel, 2020). In fact, some evidence suggests that when implemented, WFH not only reduces infrastructure costs but also increases the workforce's overall productivity (Angelici \& Profeta, 2020; Barrero et al., 2021; Bloom et al., 2015; Bolisani et al., 2020).

With the onset of the pandemic, remote working became a necessity for many (Shao et al., 2021; Zhang et al., 2021). Indeed, to ensure the continuity of services, governments, companies and institutions worldwide suddenly adopted approaches and systems to enable people to work from home (Bonacini et al., 2021). For instance, WFH reached peaks of $40 \%$ in eurozone countries (Fana et al., 2020).

Despite these adversities, with differing degrees of efficiency and effectiveness, citizens all over the world have been offered a certain amount of continuity regarding key services. For instance, with regard to education, the United Nations (2020) has reported that during the height of the pandemic, about 80-85 percent of students in high-income countries were involved in alternative e-learning activities, compared to only 50 percent in low-income countries.

Some researchers have suggested that COVID-19 has exposed many workers to the advantages and disadvantages of WFH, potentially increasing their awareness of possible (alternative) work modalities and opening the opportunity to reduce the stigma around WFH (Barrero et al., 2021; Harrington \& Emanuel, 2020). For instance, according to a recent global Ipsos survey involving 12,500 employees across 29 countries, 30\% of respondents who have experienced WFH would consider looking for another job if requested to return full-time to their office (Boyon, 2021).

Certainly, during COVID-19, companies and workers have invested in physical, digital and human capabilities (Barrero et al., 2021) to adapt to the necessity of WFH. Moreover, rapid technological advancements have supported the switch to WFH, with new and updated digital systems for online and remote services developed to sustain services and activities (Renu, 2021 
- e.g., conference, team management and exchanges, applied robotics solutions, e-health, online entertainment) including conferences, team management and exchange, applied robotics solutions, e-health, and online entertainment.

The technological, human and organizational investments made during COVID-19 may increase the impetus to rethink work practices and workplaces already initiated before the pandemic crisis (Lund et al., 2021). In this sense, WFH whether full- or part-time is likely to become a new job condition for a significant fraction of workers worldwide. The portion of the workforce that will aim to operate according to the WHF modality is hard to predict, and ultimately the decision to implement and support it in private and public services will be determined by cost-benefit considerations and by looking at the indexes of productivity and performance (European Commission, 2020). To inform decisions regarding the implementation of the WFH modality, it is however important to go further than economics and performance considerations and to additionally consider the impact of WFH on individuals, in order to avoid its well-known negative effects, such as increased workload and stress (Mallia \& Ferris, 2000; Troup \& Rose, 2012), isolation and decreased socialization (Dolan, 2011; Morgan \& Symon, 2002; Raffaele \& Connell, 2016), lack of placeness (Riva et al., 2021), and work-life balance issues (Aczel et al., 2021). Ultimately, deciding to implement or expand practices of WFH should also be driven by the possibility to monitor, evaluate and compare the overall experience of employees under such new working conditions in order to optimize and customize these emerging sociotechnical systems (i.e., systems to exchange information and perform actions among humans, supported by technology and regulated by spatial, internal and external normative constraints) to the needs of both workers and employers (Fox, 1995). 


\section{Experience of working from home remotely}

WFH is more than simply performing at home the work conventionally done onsite. It requires a different individual and organizational structure, which should be designed to fit the needs and the goals of employers and employees alike (Baruch, 2000). To understand how different modalities under the umbrella of WFH can be designed and compared, it is necessary to identify ways for assessing workers' subjective experience (Baruch, 2000; Wang et al., 2021), with the aim of achieving sustainable WFH modalities (Davidescu et al., 2020). Indexes of performance and productivity, as well as the amount of time spent working from home in line with contractual or informal agreements (e.g., flexibility), only provide a partial picture of the impact of WFH modalities. Indeed, monitoring in an efficient way workers' perceived quality in performing their work and their overall experience when at home is considered a key aspect for improving the success of this work modality, as perceived by workers (Aczel et al., 2021; Ipsen et al., 2020; Ipsen et al., 2021; van der Lippe \& Lippényi, 2020).

Workers' experience of WFH has been widely and inconsistently characterized. For instance, some researchers agree that the subjective experience of workers is a multifaced concept that can be measured by collecting a wide range of variables regarding aspects such as satisfaction, flexibility, and work-life balance (Angelici \& Profeta, 2020; Barrero et al., 2021; Bloom et al., 2015; Bolisani et al., 2020; Davidescu et al., 2020). Accordingly, Grant et al. (2013), focusing on the psychological impact of remote technology in the context of WFH, have suggested that workers' experience is affected by their perceived effectiveness and performance, their wellbeing and work-life balance, plus overarching elements such as their use of technology and their relationship with management. By contrast, Aczel et al. (2021) have suggested that modeling the experience of working from home necessitates attention to the negative and positive aspects of WFH compared to working onsite, considering aspects such as control over tasks, freedom, motivation and individual context (e.g., number of children at home), on top of 
perceived performance, time spent at work, well-being, and work-life balance. Alternatively, Davidescu et al. (2020) have suggested that the measurement of subjective experience should be mainly focused on collecting aspects such as satisfaction regarding one's position and work flexibility, that is, assessing the interplay between an employee's subjective reaction (satisfaction) to objective conditions such as flexibility and their working conditions.

Certainly, a worker's satisfaction, conceptualized either as the positive emotional state resulting from an individual's appraisal of their job or job experience (Kröll \& Nüesch, 2019), or as a set of an individual's attitudes toward or about a certain job (Ahmad et al., 2003), is a key aspect of the workers' overall experience. Nevertheless, how satisfaction and experience are connected is unclear in the context of WFH. In other domains, such as service and product interaction, experience is defined by an international standard (ISO 9241-210, 2019), which strongly connects experience and satisfaction with other potential aspects for a subjective assessment of a service's quality. Such a standardized definition can enable goals and measurements to be unified in the domain of service experience but is missing in the context of WFH.

Some researchers (Bentley et al., 2016; Rajanen \& Rajanen, 2020) have suggested that people's experience of complex sociotechnical systems is usually determined by a subjective reaction to objective aspects and constraints. Therefore, it seems plausible that the interplay between a subjective reaction and objective aspects is a determinant in the quality experienced by people in WFH modalities. Nevertheless, given that the multifaceted concept of working experience is not well characterized when attempting to assess the experience of working from home, researchers tend to focus on different elements of a sociotechnical system (e.g., work modality and constraints) using a wide range of methods (which are more or less qualitative) and questions (which are more or less validated), often making it difficult to compare results (Duxbury et al., 1992; Grant et al., 2019; Maruyama et al., 2009). Indeed, some researchers are quite positive about the effect of WFH modalities on people (e.g., Angelici \& Profeta, 2020; 
Bloom et al., 2015), whereas others are less positive or even negative, highlighting these modalities' detrimental impacts (e.g., Bellmann \& Hübler, 2020; de Vries et al., 2019).

Recognizing this issue, standardized scales are emerging to assess in a comparable way the elements that may be associated with the experience of WFH, for instance: i) the e-work life scale (Grant et al., 2019), which aims to assess elements associated with effectiveness, worklife balance, and well-being; ii) the advantage and disadvantage scale proposed by Ipsen et al. (2021), which seeks to model the strengths and weaknesses of WFH; iii) the technostress scale (Ragu-Nathan et al., 2008), which aims to assess the stress induced by one's interaction with technology (Molino et al., 2020); and iv) the Utrecht work engagement scale, intended as a measure of fulfillment at work (UWES, Schaufeli et al., 2006), which is often also used as an indirect measure of satisfaction in WFH studies (Molino et al., 2020; Moretti et al., 2020). As recently suggested by Grant et al. (2019), researchers investigating WFH consider different variables to model workers' experience. Nevertheless, despite variations in the objects measured, it is possible to aggregate different variables according to overarching dimensions. For instance, researchers can focus on assessing specific variables such as stress, workload or exhaustion, but despite the diversity of measures available, the overall objectives of such investigations are oriented toward assessing the same overarching concept i.e., the effect of WFH on people's well-being. Currently, a mapping of the aspects that researchers deem important for assessing the experience of remote home workers, as well as how these aspects are usually assessed, is missing. In response, the research reported here aimed - in line with the general objective of scoping reviews (Munn et al., 2018) - to systematically map the most common approaches for measuring home workers' experience. This mapping was also intended to clarify the concept of experience in the domain of WFH by proposing a qualitative reorganization of the overarching dimensions that can be measured to model workers' 
experience. Our scoping review was performed in accordance with the Preferred Reporting Items for Systematic Reviews and Meta-Analyses (PRISMA) approach (Tricco et al., 2018).

\section{Methods}

\section{Study design}

The scoping review was performed on articles examining or attempting to model the quality of experience of home workers from the past 10 years.

\section{Definition of terms}

WFH is conceptualized in this study as a modality of working from a remote locationspecifically the home — via technology, enabling employees to perform their activities in a smart and connected way. The experience of the worker is understood here as workers' perceived satisfaction and quality in performing their work from home.

\section{Research questions}

By aiming to map the current practice of assessing WFH in terms of the methods and types of tools used, and to identify the most investigated aspects as well as potential overarching dimensions used to evaluate the experience of workers, this review sought to answer the following research questions:

R1) What methodological approaches (e.g., survey, observation, interview) are usually applied to investigate the subjective experience of WFH?

R2) What variables are usually investigated using these approaches?

R3) What overarching dimensions emerge through grouping variables oriented to assessing similar relationships between workers and their work modalities? 
We intended the first two questions to help us map the most common methods applied and the variables investigated by researchers to assess workers' experience. Furthermore and in line with previous research, we assumed that the experience of home workers is a multifaceted concept, and so we attempted to aggregate variables oriented to assessing similar relevant aspects of employees' experience by proposing potential dimensions for evaluating this concept.

\section{Eligibility criteria}

In the review, we included records that:

i) focused on the evaluation of the quality perceived by remote home workers regarding their modality of work and its associated constraints, by highlighting empirically or qualitatively the main aspects that should be measured, irrespective of the COVID-19 pandemic.

ii) Discussed and measured the advantages and disadvantages of WFH or proposed validation of tools for the assessment of the workers' experience.

iii) Attempted to assess or compare the perceived experience of WFH and office work.

We excluded records that investigated remote working outside of the home or working from home without the support of technology, as well as studies focusing on:

i) either the impact of the COVID-19 pandemic on workers' quality of life or health, or disruption or changes brought about by the transition to WFH, without reflecting on key factors that may affect workers' experience.

ii) either surveying workers, modeling by data set review aspects that affect workers' productivity, or reviewing types of job arrangements or other organizational 
constraints on WFH, with no or little focus on aspects that affect people's experience of working from home.

iii) the economic or environmental sustainability of working from home, the business advantages and general economic benefits of implementing this work modality, or the sustainability of WFH in the family context, without any or with minimal reference to effects on experience or satisfaction.

iv) the social consequences of smart working enforced by COVID-19, e.g., the gender gap, and coping strategies.

v) behavioral changes resulting from legislation, rules, management/leadership and team interplay with regard to working from home owing to the pandemic crisis.

\section{Search strategy}

Records were retrieved from two of the largest literature databases-Scopus and Web of Science — using the Boolean operators (AND/OR) to combine the following keywords (see Supplementary Material 1): "Working from home," "Smart working," "Remote working," "Satisfaction," "Perceived satisfaction," "Experience," and "Perceived quality." We searched only for English language articles, conferences and book chapters. We focused on the past ten years, to collect information on recent advancements in measuring employees' experience with the WFH modality.

\section{Record categorization strategy}

The records were first classified in terms of type of study and number of participants.

Subsequently, each record was analyzed to list down the variables declared by their authors to be the object of the investigation, and tested with qualitative or reliable scales (see Supplementary Material 2). For each record, we reported the type of items used for the 
investigation as follows: i) Qualitative scales, whereby the record used its own items to investigate the dimensions at hand; ii) Adapted/validated scales, whereby the record used items adapted from previous studies or standardized reliability scales to investigate the dimensions at hand; or iii) Mixture scales, whereby the record used a mixture of qualitative and adapted/validated items to investigate the dimensions at hand.

The list of variables was used to group aspects by similarity, producing a set of clustered overarching dimensions. For instance, despite the fact that studies focusing on, for instance, how much people feel they matter at work (Prihadi et al., 2021), typically use different measures from those investigating, for example, how much a person is engaged personally or by others in their work activity (Moretti et al., 2020), both aim to attain workers' insights regarding the same relationship, i.e., between individuals and their job function and activities. Two authors of the present study (MLDF, SB) independently categorized by a grounded approach (Stern, 1980) the records in potential overarching dimensions when, despite using different measures, researchers aimed to inform similar relationships between the workers and their modality of work. Agreement between the two authors was achieved via discussion, and the final set of dimensions was discussed and approved by all the authors.

Finally, we investigated how the overarching dimensions we identified have typically been investigated by researchers in terms of qualitative and quantitative scales.

\section{Results}

A total of 323 products were derived from Scopus and the Web of Science (Figure 1). A further two records were added manually following a reading of online resources. After removing 27 duplicates, a scan of the 298 remaining records by title and abstract was performed by two of the authors (MLDF, SB). Articles that mentioned in their scope either a theoretical or empirical testing of aspects related to the quality experienced by workers in the 
context of remote WFH and that also suggested specific approaches or measures regarding this subject were retained.

Only about $19.5 \%$ (58) of the records were retained, as a large proportion of the studies were focused either on the economic and business advantages of implementing WFH, on the environmental sustainability of working from home, or on COVID-19 related aspects of WFH like the forced transition to this modality. The full texts of these 58 records were then scanned by three of the authors (MLDF, SB, GB) to identify articles proposing or discussing methods for assessing the subjective experience of WFH. After removing 26 records, a further two records were retrieved from the reference list. The final list comprised 34 records (Aczel et al., 2021; Ali et al., 2021; Angelici \& Profeta, 2020; Bellmann \& Hübler, 2020; Bolisani et al., 2020; Chong et al., 2020; Craig et al., 2021; Darouei \& Pluut, 2021; Davidescu et al., 2020; de Vries et al., 2019; Decastri et al., 2020; Di Tecco et al., 2021; Eng et al., 2010; Grant et al., 2019; Ipsen et al., 2020; Ipsen et al., 2021; Langvik et al., 2021; Mazzucchelli, 2017; Molino et al., 2020; Moretti et al., 2020; Nakrošienè et al., 2019; Negulescu \& Doval, 2021; Prihadi et al., 2021; Schade et al., 2021; van der Lippe \& Lippényi, 2020). 


\section{Figure 1}

A pictorial view of the review process in accordance with the flowchart of the PRISMA guidelines (Liberati et al., 2009)

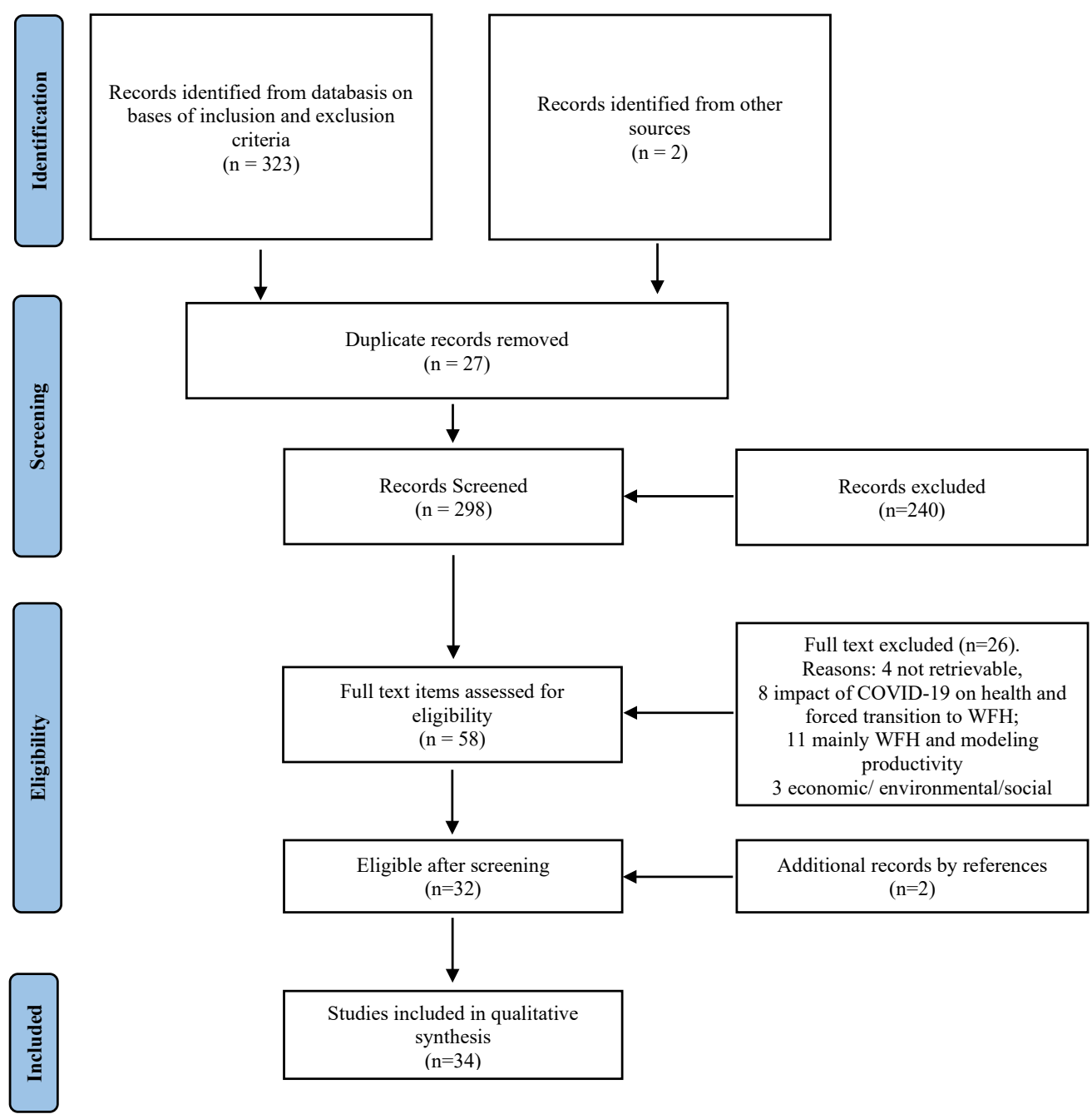

As shown in Table 1, 59\% of the studies in our pool used surveys, whereas $15 \%$ used a theoretical analysis or a qualitative approach. In $29 \%$ of cases, a combination of a survey and either a qualitative approach or a validation of scales was used, while $18 \%$ of the studies 
involved longitudinal observations. Only one record (Bloom et al., 2015) proposed a randomized control experiment. The number of participants involved in the studies varied from 12 families to 11,011 individual participants.

\section{Table 1}

Type of research approach and number of participants in each study. Records are presented in ascending order by year

\begin{tabular}{|c|c|c|c|}
\hline $\begin{array}{l}\text { Study } \\
\text { ID }\end{array}$ & Authors, year & Type of study & $\begin{array}{l}\text { Number of } \\
\text { participants }\end{array}$ \\
\hline 1 & Eng et al. (2010) & Survey & 1,103 \\
\hline 2 & Nansen et al. (2010) & $\begin{array}{l}\text { Qualitative observation } \\
\text { (longitudinal) }\end{array}$ & $\begin{array}{l}12 \text { families ( } 24 \\
\text { participants) }\end{array}$ \\
\hline 3 & Wang and Ronen (2011) & Theoretical/review & N/A \\
\hline 4 & Troup and Rose (2012) & Survey & 856 \\
\hline 5 & Koopmans et al. (2013)* & Scale validation & 1,181 \\
\hline 6 & Koopmans et al. (2014)* & Interview and survey & $\begin{array}{l}695 \text { (expert interview } \\
\text { and survey), } 253 \\
\text { expert survey }\end{array}$ \\
\hline 7 & Raguseo et al. (2014) & Interview and survey & $\begin{array}{l}100 \text { (survey), } 49 \\
\text { (interview) }\end{array}$ \\
\hline 8 & Tustin (2014) & Focus group and survey & 310 \\
\hline 9 & Bloom et al. (2015) & $\begin{array}{l}\text { Survey and randomized } \\
\text { experiment } \\
\text { (longitudinal) }\end{array}$ & 249 \\
\hline
\end{tabular}


$10 \quad$ Malik et al. (2016)

$11 \quad$ Mazzucchelli (2017)

12 de Vries et al. (2019)

13 Grant et al. (2019)

$14 \quad$ Nakrošienė et al. (2019)

$15 \quad$ Angelici and Profeta (2020)

16 Bellmann and Hübler (2020)

17 Bolisani et al. (2020)

18 Chong et al. (2020)

19 Davidescu et al. (2020)

20 Decastri et al. (2020)

21 Ipsen et al. (2020)

22 Molino et al. (2020)

23 Moretti et al. (2020)

$24 \quad$ van der Lippe and Lippényi (2020)

25 Aczel et al. (2021)

$26 \quad$ Ali et al. (2021)

27 Craig et al. (2021)

28 Darouei and Pluut (2021)

29 Di Tecco et al. (2021)

$30 \quad$ Ipsen et al. (2021)
Survey

117

Interview and survey

1,560 (workers), 160

(managers)

Diary study and survey $\quad 61$

(longitudinal)

Scale validation

260

$\begin{array}{ll}\text { Survey } & 128\end{array}$

Survey (longitudinal) $\quad 310$

Survey (longitudinal) 50

Survey

931

Survey

128

Survey

220

Interview

57

Scale validation

4,643

Survey and scale

1,627

validation

Survey

51

Survey

11,011

Survey

704

Survey

466

Theoretical/review

N/A

Survey (longitudinal) 34

Survey

187

Scale validation

5,748 
$31 \quad$ Langvik et al. (2021)

32 Negulescu and Doval (2021)

33 Prihadi et al. (2021)

$34 \quad$ Schade et al. (2021)
Survey

1,133

Theoretical/review

Survey

Survey
N/A

400

199

* Articles proposing relevant measures and aspects to assess workers' experience not only of WFH modalities.

Twenty-three percent of the studies only used a qualitative scale (e.g., individually defined items) for their analysis, 39\% used scales with adapted items from previous literature or standardized scales, and 39\% used a combination of qualitative and adapted questions.

As reported in Table 2, for each item we looked at which types of scales were used for the assessment, and we extrapolated 153 key variables reported by the researchers as part of their study as important for assessing the quality perceived by remote home workers (see Supplementary Material 1 for a full description of the measures). Moreover, $48 \%$ of the records reported the list of questions used to collect data, while only in $45 \%$ of the cases was the reliability of the items used for investigation discussed by the authors.

\section{Table 2}

Types of measurements (scales), items and reliability of items reported (yes/no) by the researchers, and key variables investigated in each study. Types of measurements are presented according to the following three categories: i) Qualitative scales - the record used its own items to investigate the dimensions at hand; ii) Adapted/validated scales - the record used items adapted from previous studies or standardized reliability scales to investigate the dimensions at hand; and iii) Mixture scales - the record used a mixture of qualitative and adapted/validated items to investigate the dimensions at hand. Review studies (Craig et al., 
2021; Negulescu \& Doval, 2021; Wang \& Ronen, 2011) were excluded from the analysis of the types of items

\begin{tabular}{|c|c|c|c|c|}
\hline $\begin{array}{l}\text { Study } \\
\text { ID }\end{array}$ & Type of scale & $\begin{array}{l}\text { Items } \\
\text { reported }\end{array}$ & $\begin{array}{l}\text { Reliability } \\
\text { reported }\end{array}$ & Key variables investigated \\
\hline 1 & Mixture & No & No & $\begin{array}{l}\text { - Work and family conflict } \\
\text { - Management support and } \\
\text { influence }\end{array}$ \\
\hline 2 & Qualitative & No & N/A & $\begin{array}{l}\text { - Management of time and } \\
\text { spatial constraints and } \\
\text { conflicts }\end{array}$ \\
\hline 3 & N/A & N/A & N/A & $\begin{array}{l}\text { - Loyalty toward } \\
\text { company, peers and role } \\
\text { - Job satisfaction }\end{array}$ \\
\hline 4 & Mixture & Yes & No & $\begin{array}{l}\text { Living situation, } \\
\text { including time spent on } \\
\text { childcare (average hours } \\
\text { per week) and } \\
\text { distribution of work and } \\
\text { home tasks } \\
\text { - Performance } \\
\text { - Job satisfaction }\end{array}$ \\
\hline 5 & Adapted/validated & Yes & Yes & $\begin{array}{l}\text { - Individual task and } \\
\text { contextual performance }\end{array}$ \\
\hline
\end{tabular}




\begin{tabular}{|c|c|c|c|c|}
\hline & & & & $\begin{array}{l}\text { - Counterproductive } \\
\text { behavior }\end{array}$ \\
\hline 6 & Adapted/validated & Yes & Yes & $\begin{array}{l}\text { - Individual task and } \\
\text { contextual performance } \\
\text { - Counterproductive } \\
\text { behavior }\end{array}$ \\
\hline 7 & Mixture & No & No & $\begin{array}{l}\text { - Flexibility in the job } \\
\text { - Management of work-life } \\
\text { balance } \\
\text { - Layout and technology } \\
\text { elements } \\
\text { - Innovativeness of } \\
\text { management }\end{array}$ \\
\hline 8 & Mixture & Yes & No & $\begin{array}{l}\text { - Advantages and } \\
\text { disadvantages of WFH } \\
\text { - Job satisfaction } \\
\text { - Commuting duty and } \\
\text { flexibility of the job } \\
\text { - Work-life balance } \\
\text { aspects e.g., more time } \\
\text { with family and better } \\
\text { management of time } \\
\text { - Well-being aspects e.g., } \\
\text { improved quality of life }\end{array}$ \\
\hline
\end{tabular}




\begin{tabular}{|c|c|c|c|c|}
\hline 9 & Adapted/validated & Yes & Yes & $\begin{array}{l}\text { - Performance } \\
\text { - Commuting duty } \\
\text { - Work-life situation } \\
\text { - Satisfaction (life and } \\
\text { - Exhark) } \\
\text { - Attitude toward work }\end{array}$ \\
\hline 10 & Mixture & Yes & Yes & $\begin{array}{l}\text { - Perceived value of WFH } \\
\text { - Family and work values } \\
\text { - Favorable attitude toward } \\
\text { WFH } \\
\text { - Motivational factors } \\
\text { - intentions) } \\
\text { Organization of the work } \\
\text { environment and job }\end{array}$ \\
\hline 11 & Qualitative & No & No & $\begin{array}{l}\text { - Family-work } \\
\text { reconciliation } \\
\text { - Flexibility } \\
\text { - Lack of autonomy and } \\
\text { support } \\
\text { - Advantages and } \\
\text { disadvantages }\end{array}$ \\
\hline
\end{tabular}




\begin{tabular}{|c|c|c|c|c|}
\hline 12 & Mixture & Yes & No & $\begin{array}{l}\text { - Engagement } \\
\text { - Organizational } \\
\text { commitment } \\
\text { - Exchange with manager } \\
\text { - Social isolation }\end{array}$ \\
\hline 13 & Adapted/validated & Yes & Yes & $\begin{array}{l}\text { - Work-life interference } \\
\text { - Flexibility } \\
\text { - Well-being } \\
\text { - Organizational aspects } \\
\text { that affect WFH }\end{array}$ \\
\hline 14 & Qualitative & No & No & $\begin{array}{l}\text { - Need to communicate } \\
\text { with colleagues } \\
\text { - Commuting and work- } \\
\text { life balance e.g., taking } \\
\text { care of family, WFH for } \\
\text { sickness } \\
\text { - Suitability of working } \\
\text { space at home; } \\
\text { - Supervisor's trust and } \\
\text { support } \\
\text { Access to organization's } \\
\text { documents }\end{array}$ \\
\hline
\end{tabular}




\begin{tabular}{|c|c|c|c|c|}
\hline & & & & $\begin{array}{l}\text { - Time management and } \\
\text { work home in productive } \\
\text { - Satisfaction } \\
\text { - Advantages of WFH } \\
\text { - Self-reported } \\
\text { productivity }\end{array}$ \\
\hline 15 & Mixture & No & No & $\begin{array}{l}\text { - Flexibility } \\
\text { - Freedom of managing } \\
\text { - } \text { time and work activities } \\
\text { - } \text { - Well-being } \\
\text { - Work-life balance } \\
\text { - Satisfaction }\end{array}$ \\
\hline 16 & Mixture & No & No & $\begin{array}{l}\text { - Job satisfaction } \\
\text { - Improved work-life } \\
\text { - Walance } \\
\text { - Job characteristics and } \\
\text { organizational aspects } \\
\text { - Commitment information } \\
\text { - Collegiality of } \\
\text { organization }\end{array}$ \\
\hline
\end{tabular}




\begin{tabular}{|c|c|c|c|c|}
\hline 17 & Adapted/validated & No & No & $\begin{array}{l}\text { - Individual advantages } \\
\text { and disadvantages of } \\
\text { WHF }\end{array}$ \\
\hline 18 & Adapted/validated & No & No & $\begin{array}{l}\text { - Stress } \\
\text { - Exhaustion } \\
\text { - Withdrawal behavior } \\
\text { - Job satisfaction }\end{array}$ \\
\hline 19 & Qualitative & Yes & No & $\begin{array}{l}\text { - Flexibility of job and } \\
\text { time } \\
\text { - Adaptability of working } \\
\text { space organization and } \\
\text { technology } \\
\text { - Job satisfaction } \\
\text { - Increased productivity } \\
\text { and efficiency } \\
\text { Interpersonal } \\
\text { relationships } \\
\text { Personal comfort and } \\
\text { motivation } \\
\text { Management of working }\end{array}$ \\
\hline 20 & Qualitative & No & No & $\begin{array}{l}\text { - Productivity } \\
\text { - Management of work-life } \\
\text { balance }\end{array}$ \\
\hline
\end{tabular}




\begin{tabular}{|c|c|c|c|c|}
\hline & & & & $\begin{array}{l}\text { - Improved well-being of } \\
\text { workers } \\
\text { - Layout of the space and } \\
\text { information and } \\
\text { technology infrastructure } \\
\text { - Quality of management } \\
\text { and organization-related } \\
\text { aspects }\end{array}$ \\
\hline 21 & Adapted/validated & Yes & Yes & $\begin{array}{l}\text { - Advantages and } \\
\text { disadvantages of WFH }\end{array}$ \\
\hline 22 & Adapted/validated & Yes & Yes & $\begin{array}{l}\text { - Improved work-life } \\
\text { balance } \\
\text { - Stress in WFH } \\
\text { - Stress induced by } \\
\text { technology }\end{array}$ \\
\hline 23 & Adapted/validated & No & Yes & $\begin{array}{l}\text { - Engagement } \\
\text { - Pain } \\
\text { - Stress } \\
\text { - Avoidance } \\
\text { - Flexibility in tasks } \\
\text { - Living situation } \\
\text { - Perceived productivity } \\
\text { - Advantages and } \\
\text { disadvantages of WFH }\end{array}$ \\
\hline
\end{tabular}




\begin{tabular}{|c|c|c|c|c|}
\hline 24 & Mixture & No & Yes & $\begin{array}{l}\text { - Work performance } \\
\text { - Type of WFH oversight } \\
\text { - Perceived autonomy } \\
\text { - Job satisfaction } \\
\text { - Job demands } \\
\text { - Job position } \\
\text { - Situation at home, } \\
\text { commuting and work-life } \\
\text { balance }\end{array}$ \\
\hline 25 & Qualitative & Yes & No & $\begin{array}{l}\text { - Work efficiency } \\
\text { - Well-being } \\
\text { - Living situation and } \\
\text { - Advark-life balance } \\
\text { disadvantages of WFH }\end{array}$ \\
\hline 26 & Qualitative & No & Yes & $\begin{array}{l}\text { - Job satisfaction } \\
\text { - Motivation } \\
\text { - Organizational aspects } \\
\text { - Personal fears and } \\
\text { anxiety }\end{array}$ \\
\hline 27 & $\mathrm{~N} / \mathrm{A}$ & $\mathrm{N} / \mathrm{A}$ & N/A & $\begin{array}{l}\text { - Management of breaks } \\
\text { and time }\end{array}$ \\
\hline
\end{tabular}




\begin{tabular}{|c|c|c|c|c|}
\hline & & & & $\begin{array}{l}\text { - Management of elements } \\
\text { in the work space/layout } \\
\text { - Positive effect on well- } \\
\text { being }\end{array}$ \\
\hline 28 & Adapted/validated & No & Yes & $\begin{array}{l}\text { - Engagement } \\
\text { - Exhaustion } \\
\text { - Attitude toward the } \\
\text { - Worganization } \\
\text { - Work-life conflicts }\end{array}$ \\
\hline 29 & Mixture & Yes & Yes & $\begin{array}{l}\text { - } \text { Engagement } \\
\text { - Work-life balance } \\
\text { - Job satisfaction } \\
\text { - Well-being } \\
\text { - Demands of and control } \\
\text { - } \text { over the work activity } \\
\text { - Management support } \\
\text { - Rules and changes at the } \\
\text { organizational level }\end{array}$ \\
\hline 30 & Adapted/validated & Yes & Yes & $\begin{array}{l}\text { - Job satisfaction } \\
\text { - Advantages and } \\
\text { disadvantages of WFH }\end{array}$ \\
\hline
\end{tabular}




\begin{tabular}{|c|c|c|c|c|}
\hline & & & & $\begin{array}{l}\text { - Perceived work-life } \\
\text { balance } \\
\text { - Perceived work } \\
\text { - Perceived control } \\
\text { - Homerwork } \\
\text { - Work uncertainties } \\
\text { - Inadequate tools }\end{array}$ \\
\hline 31 & Mixture & No & No & $\begin{array}{l}\text { - Personality } \\
\text { - Job satisfaction } \\
\text { - Stress } \\
\text { - Socialization needs } \\
\text { - Type of flexibility }\end{array}$ \\
\hline 32 & N/A & N/A & N/A & $\begin{array}{l}\text { - Time management } \\
\text { - Space organization, setup } \\
\text { and management }\end{array}$ \\
\hline 33 & Adapted/validated & Yes & Yes & $\begin{array}{l}\text { - Mattering } \\
\text { - Self-esteem } \\
\text { - Extraversion } \\
\text { - Work self-efficacy }\end{array}$ \\
\hline 34 & Mixture & Yes & Yes & $\begin{array}{l}\text { - Work-related basic needs } \\
\text { satisfaction } \\
\text { - Job role }\end{array}$ \\
\hline
\end{tabular}




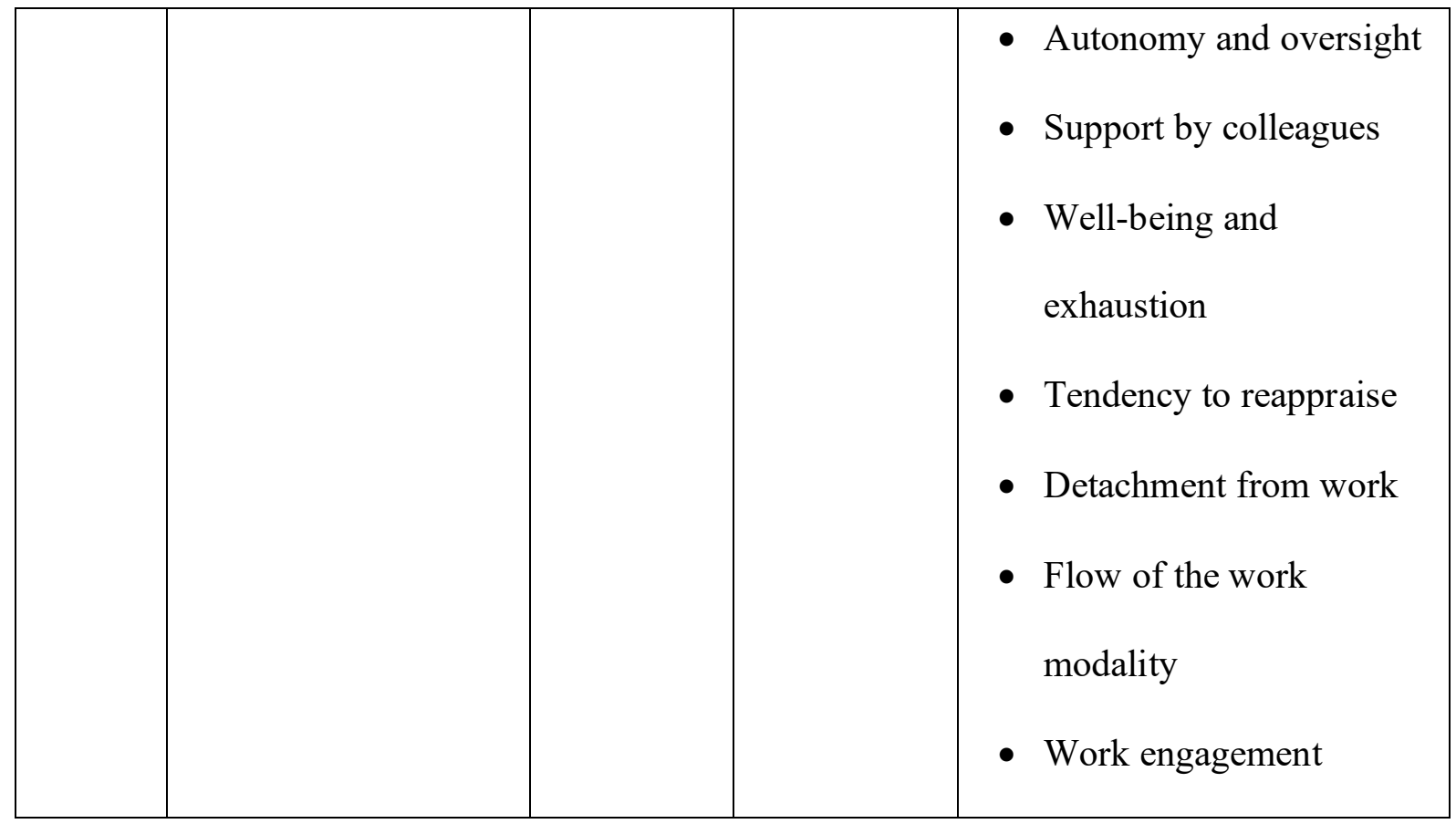

Ten overarching dimensions were identified as follows:

1. Engagement with work (ENG): this dimension contains aspects investigated in 13 records (Bellmann \& Hübler, 2020; Bloom et al., 2015; Chong et al., 2020; Darouei \& Pluut, 2021; de Vries et al., 2019; Decastri et al., 2020; Di Tecco et al., 2021; Koopmans et al., 2013; Koopmans et al., 2014; Moretti et al., 2020; Prihadi et al., 2021; Schade et al., 2021; van der Lippe \& Lippényi, 2020). These records assessed variables associated with workers' individual relationships with their work in general, their work function and activities. This dimension also includes workers' sense of fulfillment in doing their work, their sense of caring about their work and their perception that they matter, or their attitude and behavior toward their work that might affect (if negative) their willingness to work e.g., counterproductivity.

2. Flexibility (FLEX): This dimension contains aspects considered in 19 records (Angelici \& Profeta, 2020; Bloom et al., 2015; Craig et al., 2021; Davidescu et al., 2020; de Vries et al., 2019; Decastri et al., 2020; Eng et al., 2010; Grant et al., 2019; Langvik et al., 2021; 
Mazzucchelli, 2017; Moretti et al., 2020; Nakrošienè et al., 2019; Nansen et al., 2010;

Negulescu \& Doval, 2021; Raguseo et al., 2014; Schade et al., 2021; Tustin, 2014; van der Lippe \& Lippényi, 2020; Wang \& Ronen, 2011). This dimension pertains to the assessment of variables such as the amount of flexibility in the job (e.g., working from home weekly) and perceived freedom to work at one's own pace, i.e., time, space and resource management. This dimension also includes aspects related to the amount of oversight imposed on workers and perceived constraints on carrying out one's work in a flexible way.

3. Health and well-being (HEAL): This dimension includes aspects presented in 16 records (Aczel et al., 2021; Angelici \& Profeta, 2020; Bloom et al., 2015; Chong et al., 2020; Craig et al., 2021; Darouei \& Pluut, 2021; Decastri et al., 2020; Di Tecco et al., 2021; Grant et al., 2019; Koopmans et al., 2013; Koopmans et al., 2014; Langvik et al., 2021; Molino et al., 2020; Moretti et al., 2020; Schade et al., 2021; Tustin, 2014). The variables investigated are related to the WFH modalities perceived effects on people's health and well-being, for instance, fatigue, workload, stress (also induced by technology, Molino et al., 2020), pain, avoidance, and exhaustion induced by stress and withdrawal behavior.

4. Layout and technology (LAY). This dimension is apparent in six records (Craig et al., 2021; Davidescu et al., 2020; Decastri et al., 2020; Nakrošienė et al., 2019; Negulescu \& Doval, 2021; Raguseo et al., 2014). The LAY dimension considers organizational and environmental elements that may affect workers' experience, such as the physical adaptability of the workspace and furniture, and the adaptability and functionality of the technology e.g., the quality of the technological setup, and issues in usage.

5. Organizational and job-related aspects (ORG): This dimension contains aspects from 11 records (Ali et al., 2021; Bellmann \& Hübler, 2020; Darouei \& Pluut, 2021; de Vries et al., 2019; Eng et al., 2010; Grant et al., 2019; Malik et al., 2016; Nakrošienė et al., 2019; 
Raguseo et al., 2014; Schade et al., 2021; Wang \& Ronen, 2011). The ORG dimension is focused on the quality of the relationship between workers and their organization, including variables such as loyalty and trust toward the company e.g., uncertainty regarding the work, but also trust toward managers and colleagues, and support provided by management and colleagues that may compromise the aforementioned relationship. The ORG dimension also includes the assessment of job position, type of company, salary, and work demands and pressure, for instance, to model differences in workers' experience.

6. Performance, productivity and efficiency (PERF): This dimension contains aspects investigated in 12 records (Aczel et al., 2021; Angelici \& Profeta, 2020; Bloom et al., 2015; Chong et al., 2020; Koopmans et al., 2013; Koopmans et al., 2014; Moretti et al., 2020; Nakrošienė et al., 2019; Prihadi et al., 2021; Tustin, 2014; van der Lippe \& Lippényi, 2020; Wang \& Ronen, 2011). It contains quantitative performance measures including indexes, and reported data on increases in productivity, task complexity, time on task, and the number of goals achieved in a set period of time. Moreover, it includes subjective perceptions of performance, such as regarding the efficiency or productivity of workers.

7. Personal needs and style (PERS): This dimension appears in nine records (Ali et al., 2021; Bellmann \& Hübler, 2020; Chong et al., 2020; de Vries et al., 2019; Langvik et al., 2021; Malik et al., 2016; Nakrošienė et al., 2019; Prihadi et al., 2021; Schade et al., 2021). It includes the assessment of individual needs and characteristics, personality traits and style, which may affect people's activities at (and toward their) work, such as the need to interact/communicate with others, the need for socialization or comfort, security and support, and personal internal motivation to perform activities in a certain way and fear and anxiety to perform due to personal reasons and style. 
8. Satisfaction (SAT): This dimension appears in 13 records (Ali et al., 2021; Angelici \& Profeta, 2020; Bellmann \& Hübler, 2020; Bloom et al., 2015; Davidescu et al., 2020; Decastri et al., 2020; Di Tecco et al., 2021; Langvik et al., 2021; Nakrošienè et al., 2019; Schade et al., 2021; Troup \& Rose, 2012; Tustin, 2014; van der Lippe \& Lippényi, 2020). It pertains to the explicit assessment of satisfaction as an individual's overall sense of satisfaction with their work, or their satisfaction with its position and modality.

9. Subjective gain (SUBJ): This includes aspects measured in 9 records (Bolisani et al., 2020; Ipsen et al., 2020; Ipsen et al., 2021; Malik et al., 2016; Mazzucchelli, 2017; Moretti et al., 2020; Nakrošienė et al., 2019; Schade et al., 2021; Tustin, 2014). It pertains to the assessment of (economic) value, forms of personal gain (also caused by external factors) that may stimulate workers to carry out their work in a certain modality, including (perceived) improvements in the flow and quality of the work done, and the perceived advantages and disadvantages of the WFH modality.

10. Work-life balance (WLB): This dimension appears in 21 records (Angelici \& Profeta, 2020; Bellmann \& Hübler, 2020; Bloom et al., 2015; Decastri et al., 2020; Eng et al., 2010; Grant et al., 2019; Malik et al., 2016; Mazzucchelli, 2017; Nakrošienè et al., 2019; Nansen et al., 2010; Raguseo et al., 2014; Troup \& Rose, 2012; Tustin, 2014). It contains aspects related to existing or perceived conflicts between work duties and duties associated with one's living situation, e.g., home duty, childcare, distance from work, the necessity to commute, and the sustainability of working from home.

To summarize the relationship between the variables investigated in the records and the proposed overarching dimensions, we estimated the percentage of how many records focused on each dimension (see Supplementary Material 3). Specifically, the results suggest that aspects associated with WLB were the most investigated in our data set (62\% of the records), 
followed by FLEX (56\%) and HEAL (47\%). Aspects concerning ENG and SAT were equally investigated (38\%), followed by PERF (35\%). Aspects associated with the other dimensions were investigated in fewer than one third of the records: ORG (32\%), SUBJ and PERS (both $26 \%)$, and LAY (18\%).

To attain insights into how the overarching dimensions were investigated by the researchers, we distinguished for each dimension when data were collected using indexes, qualitative items, items of validated scales or adapted items, or a combination (mixture) of validated, adapted and qualitative items. We used this distinction to generate a heatmap in SPSS 25 (Figure 2). As suggested in the figure, qualitative (own-made) items were widely used to measure all the clusters, with an overall mean of $50 \%$ of the clusters measured by qualitative questions across the studies. These items were used in more than one third of the cases to assess aspects regarding LAY, FLEX, WLB, ORG, SAT, PERF, and SUBJ. Questions adapted from validated scales or previous studies were used to assess almost all the clusters (the exception being LAY) as on average between $24 \%$ and $26 \%$ of the dimensions in our records were measured with these types of questions. Items from validated scales were used to measure dimensions ENG, SUBJ and HEAL in more than one third of the cases, while items adapted from previous studies (independently from the reliability of the questions) were often used to assess PERS and ENG. A combination of adapted and validated scale questions or indexes was rarely used to collect data associated with all the dimensions.

\section{Figure 2}

Heatmap of the types of scales (including indexes) reported in the records to assess workers' experience by measuring aspects associated with the different overarching dimensions. 
Percentages are reported as proportions. Review studies (Craig et al., 2021; Negulescu \&

Doval, 2021; Wang \& Ronen, 2011) were excluded from this analysis

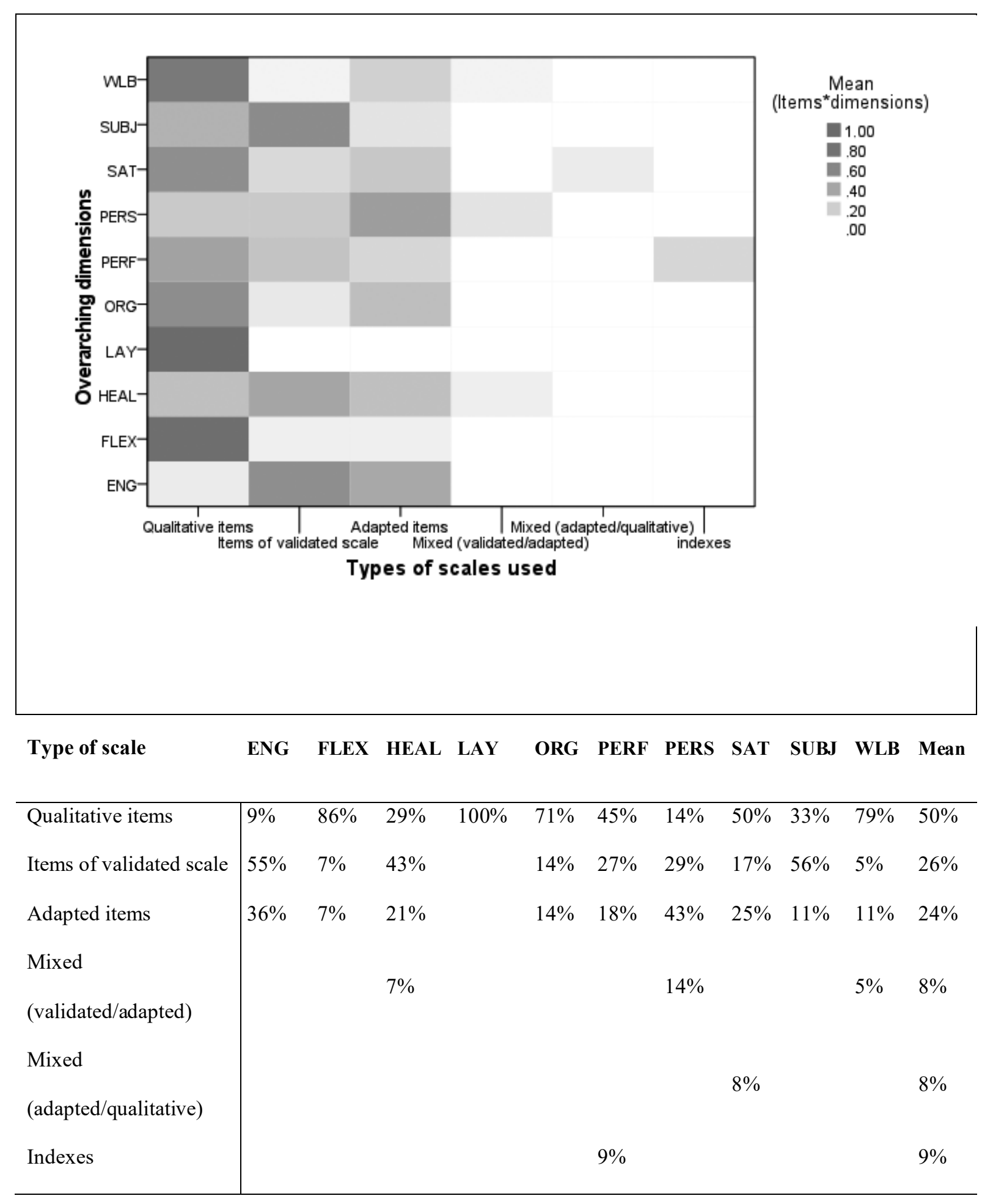




\section{Discussion}

The results of the qualitative synthesis reinforce the idea that workers' subjective experience requires that multiple aspects be investigated. Below we summarize the results in line with our research questions.

\section{Methodological approaches that researchers commonly apply to investigate workers' subjective experience of WFH (R1)}

Distributing questionnaires to workers represents the most commonly used approach for investigating workers' subjective experience of WFH. Qualitative approaches such as interviews have also been used in combination with scales, either to focus on specific aspects or to model relationships among aspects that affect the experience. Purely qualitative studies and control experiments have less commonly been used to investigate experience of WFH. Moreover, longitudinal observations are also performed, suggesting the idea that some researchers consider the experience of workers as an aspect that is changing and should be observed over time. This resonates with the definition of experience in other domains, such as the one of service and user experience (ISO 9241-210, 2019).

\section{Variables that are usually investigated by researchers (R2)}

Despite the fact that the terminology used in different studies varies substantially, in many cases researchers have gathered — through diverse approaches, albeit mainly adopting validated scales — data to assess similar and connected key aspects. Out of the 153 variables declared by the researchers in our data set, in fewer than $50 \%$ of the cases were the items and the reliability reported. Our qualitative analysis of the records suggests that at least ten dimensions can affect the overall experience of working from home. 


\section{Overarching dimensions to assess the multiple aspects associated with remote workers'} experience (R3)

The variables that we originally clustered as WLB and FLEX are the most commonly investigated, especially because these have also often been used to profile workers and their (contractual and living) conditions, as well as how these aspects affect their overall experience. From a subjective point of view, monitoring workers' satisfaction regarding their work-life balance or the flexibility offered by their company may provide useful indicators for managers. For instance, sudden drops may imply issues with employees' working modality and indicate that remedial actions are needed to maximize their experience. Other primary concerns for researchers are workers' HEAL, ENG and SAT, which could represent their subjective reactions to their working conditions, and declines in any of them may also affect their PERF. Performance can be observed using indexes (Bloom et al., 2015) or through measuring time spent on particular tasks. Furthermore, from a subjective point of view, focusing on workers' perceptions of improved productivity (Nakrošienė et al., 2019) may provide information on the relationship between productivity and experience. Moreover, to monitor subjective perspectives regarding ORG and LAY — and thereby (changes in) the relationship between workers and their organization, or issues due to the technological or environmental setup - it may be useful to measure, for instance, loyalty toward the company or satisfaction with technology. Finally, it may be helpful to assess how the same sociotechnical system of working is perceived by people with different types of SUBJ and PERS, in order to provide insights into how best to design or alter a WFH modality that can suit different people. Combining all these dimensions may provide a full picture of workers' experience and support decision making regarding the implementation or modification of WFH practices. 
The dimensions we have identified have mainly been assessed using informal questions, supporting the idea that there is an increasing need for reliable and comparable ways of evaluating aspects connected to the experience of WFH (Duxbury et al., 1992). Looking at our data, this seems particularly relevant for aspects that belong to WLB and FLEX, as well as those related to SAT, PERF, ORG and LAY. When it comes to the assessment of ENG, HEAL and SUBJ, researchers can benefit from the use of validated scales or adapted questions from previous studies. Furthermore, aspects such as PERS and SAT may benefit from validated scales, although it seems that adapted items are generally preferred by researchers. The use of qualitative and informal questions to study workers' experience is not a problem per se, but because the data collected and the aspects investigated in the domain of WFH are hard to compare, the risk is that decisions about implementing or changing WFH practices in companies and institutions will be made by overrating the importance or the risks of certain aspects based on partial insights regarding workers' experience.

\section{A tentative definition of WFH experience}

The 10 dimensions that emerged from this analysis can be used to propose an original tentative unifying definition of workers' experience as follows.

Home workers' experience is a multifaceted concept, which may vary and should be monitored over time (Angelici \& Profeta, 2020; Bellmann \& Hübler, 2020; Bloom et al., 2015; Darouei \& Pluut, 2021; de Vries et al., 2019; Nansen et al., 2010). It is affected by workers' living situation (WLB, contractual (FLEX) constraints, well-being (HEAL), sense of engagement (ENG) and satisfaction (SAT) with their work, and perceived performance and productivity (PERF). Moreover, their relationship with their organization (ORG) and the physical organization of their work environment and technology (LAY) may negatively or positively affect their experience, together with personal differences in terms of subjective 
gain (SUBJ) or personal needs and style (PERS). All these aspects, when assessed and monitored over time, can provide a full picture of workers' experience and support decision making regarding how best to implement or change WFH practices.

Such a definition of experience represents an original and inclusive perspective of the quality perceived by home workers to support decision making with regard to the design of the WFH modalities at a systemic level. Nakrošienė et al. (2019), focusing on WFH by taking a job demands-resources perspective, have recently proposed a list of 10 aspects that researchers should consider in their assessments of WFH: "time-planning skills, possibility to work during the most productive time, reduced time for communication with co-workers, possibility to work from home in case of sickness, supervisor's trust; supervisor's support, possibility to save on travel expenses, possibility to take care of family members, suitability of the working place at home and possibility to access the organization's documents from home."(Nakrošienè et al., 2019, p. 96). All these aspects are included in our dimensions (FLEX, WLB, PERS, SUBJ, ORG, SAT, LAY, WLB), although our analysis has also added aspects related to engagement (ENG) and health (HEAL), which have been widely investigated in the existing literature.

The main limitation of the present study is that we have proposed a set of overarching dimensions that emerged from our analysis of the literature. A future study should aim to extend or revise the dimensions we have proposed by involving experts and employee panels in interviews in order to find consensus. Nevertheless, despite this limitation, this scoping review has mapped approaches and measures of home workers' experience, highlighted key aspects that are commonly investigated and suggested a potential unifying definition of remote workers' experience. 


\section{Conclusion}

An essential part of the "new normal" after the COVID-19 pandemic will be a revision of the modality of work (Bonacini et al., 2021). Certainly, we have learned that several tasks, if not certain jobs, can be done from home with a minimal amount of effort. Nevertheless, the shift toward this new normal needs to be monitored. Mistakes in the design of sociotechnical systems, such as working organizations, may go unseen until the consequences are perceivable e.g., the performance of some workers suddenly decreases, or many workers decide concurrently to leave their jobs. Continuous measurements and agreement on ways of assessing WFH are necessary to benchmark different modalities of remote working. This will facilitate the exchange and diffusion of best practices among companies and institutions, which will be especially important if working from home becomes a typical condition for a growing group of employees (Barrero et al., 2021). Therefore, it is necessary to unify the domain of WFH, which is currently characterized by differences in terminology, objectives and ways of assessing aspects associated with workers' experience. Some standardized tools for measuring a limited set of aspects associated with workers' experience are currently available (Grant et al., 2019; Ragu-Nathan et al., 2008; Schaufeli et al., 2006; Schaufeli et al., 2017). However, the same cannot be said for either a battery of items with the potential to combine measurements of experience or a unified perspective regarding aspects that should be assessed.

This article has contributed to this effort to find a consolidated way of evaluating the experience of WFH by mapping the most commonly assessed aspects and how these are usually measured by researchers. Moreover, we have defined home workers' experience based on insights from the literature. Although further validation is needed, such a definition and its elements should be intended as an initial driver to support researchers to fully account for the workers' perspective when assessing WFH systems. Our list of dimensions can be 
used by experts as a checklist for establishing aspects to assess or monitor in order to improve workers' experience of carrying out their profession from home.

\section{References}

Aczel, B., Kovacs, M., van der Lippe, T., \& Szaszi, B. (2021). Researchers working from home: Benefits and challenges. PLoS ONE, 16(3), e0249127. https://doi.org/10.1371/journal.pone.0249127

Ahmad, K. Z., Alwee, S. H. S., Yusoff, Z. Z. M., Osman, S. I. W., \& Tuah, S. N. A. (2003). The Association between ethical decision-making, job satisfaction, organisational commitment and selected demographic variables. Malaysian Management Journal, 7(2), 1-11. https://doi.org/ $10.32890 / \mathrm{mmj} .7 .2 .2003 .8749$

Ali, S., Alam, B. F., Noreen, S., Anwar, M., Qazi, S. H., \& Hussain, T. (2021). Motivation and job satisfaction among medical and dental college faculty in Pakistan amid the COVID-19 outbreak. Work, 69(2), 359-366. https://doi.org/10.3233/WOR-213483

Angelici, M., \& Profeta, P. (2020). Smart-working: work flexibility without constraints. Center for Economic Studies and ifo Institute (CESifo) Working Paper n. 8165. https://ssrn.com/abstract=3556304

Barrero, J. M., Bloom, N., \& Davis, S. J. (2021). Why working from home will stick. National Bureau of Economic Research (NBER) Working Paper No. 28731. http://www.nber.org/papers/w28731

Baruch, Y. (2000). Teleworking: benefits and pitfalls as perceived by professionals and managers. New Technology, Work and Employment, 15(1), 34-49. https://doi.org/10.1111/1468005X.00063

Bellmann, L., \& Hübler, O. (2020). Working from home, job satisfaction and work-life balance robust or heterogeneous links? International Journal of Manpower, 42(3), 424-441. https://doi.org/10.1108/IJM-10-2019-0458 
Bentley, T. A., Teo, S. T., McLeod, L., Tan, F., Bosua, R., \& Gloet, M. (2016). The role of organisational support in teleworker wellbeing: A socio-technical systems approach. Applied ergonomics, 52, 207-215. https://doi.org/10.1016/j.apergo.2015.07.019

Bloom, N., Liang, J., Roberts, J., \& Ying, Z. J. (2015). Does working from home work? Evidence from a chinese experiment. Quarterly Journal of Economics, 130(1), 165-218, Article qju032. https://doi.org/10.1093/qje/qju032

Bolisani, E., Scarso, E., Ipsen, C., Kirchner, K., \& Hansen, J. P. (2020). Working from home during COVID-19 pandemic: Lessons learned and issues. Management \& Marketing. Challenges for the Knowledge Society, 15(s1), 458-476. https://doi.org/10.2478/mmcks-2020-0027

Bonacini, L., Gallo, G., \& Scicchitano, S. (2021). Working from home and income inequality: risks of a 'new normal'with COVID-19. Journal of population economics, 34(1), 303-360. https://doi.org/10.1007/s00148-020-00800-7

Boyon, N. (2021). Return to the workplace 2021 global survey. IPSOS. https://www.ipsos.com/enus/news-polls/return-to-the-workplace-global-survey

Chong, S., Huang, Y., \& Chang, C. H. D. (2020). Supporting interdependent telework employees: A moderated-mediation model linking daily COVID-19 task setbacks to next-day work withdrawal. Journal of Applied Psychology, 105(12), 1408-1422. https://doi.org/10.1037/apl0000843

Craig, C. M., Neilson, B. N., Altman, G. C., Travis, A. T., \& Vance, J. A. (2021). Applying Restorative Environments in the Home Office While Sheltering-in-Place. Human Factors. Advance online publication. https://doi.org/10.1177/0018720820984286

Darouei, M., \& Pluut, H. (2021). Work from home today for a better tomorrow! How working from home influences work-family conflict and employees' start of the next workday. Stress and Health. Advance publication online. https://doi.org/10.1002/smi.3053

Davidescu, A. A., Apostu, S. A., Paul, A., \& Casuneanu, I. (2020). Work flexibility, job satisfaction, and job performance among romanian employees-Implications for sustainable human resource management. Sustainability (Switzerland), 12(15), Article 6086.

https://doi.org/10.3390/su12156086 
de Vries, H., Tummers, L., \& Bekkers, V. (2019). The Benefits of Teleworking in the Public Sector: Reality or Rhetoric? Review of Public Personnel Administration, 39(4), 570-593. https://doi.org/10.1177/0734371X18760124

Decastri, M., Gagliarducci, F., Previtali, P., \& Scarozza, D. (2020). Understanding the use of smart working in public administration: The experience of the presidency of the council of ministers. In A. Lazazzara, F. Ricciardi, \& S. Za (Eds.), Exploring Digital Ecosystems: Organizational and Human Challenges (pp. 343-363). Springer Nature. https://doi.org/10.1007/978-3-03023665-6_25

Di Tecco, C., Ronchetti, M., Russo, S., Ghelli, M., Rondinone, B. M., Persechino, B., \& Iavicoli, S. (2021). Implementing smart working in public administration: A follow up study. Medicina del Lavoro, 112(2), 141-152. https://doi.org/10.23749/mdl.v112i2.10595

Dolan, V. (2011). The isolation of online adjunct faculty and its impact on their performance. International Review of Research in Open and Distributed Learning, 12(2), 62-77. https://doi.org/10.19173/irrodl.v12i2.793

Duxbury, L. E., Higgins, C. A., \& Mills, S. (1992). After-hours telecommuting and work-family conflict: A comparative analysis. Information Systems Research, 3(2), 173-190. https://doi.org/10.1287/isre.3.2.173

Eng, W., Moore, S., Grunberg, L., Greenberg, E., \& Sikora, P. (2010). What Influences Work-Family Conflict? The Function of Work Support and Working from Home. Current Psychology, 29(2), 104-120. https://doi.org/10.1007/s12144-010-9075-9

European Commission. (2020). COM/2020/500 final - Communication from the commission 2020 European Semester: Country-specific recommendations. https://eur-lex.europa.eu/legalcontent/EN/TXT/?qid=1591720546579\&uri=CELEX\%3A52020DC0500

EUROSTAT. (2021). Employed persons working from home as a percentage of the total employment, by sex, age and professional status (\%).

https://appsso.eurostat.ec.europa.eu/nui/show.do?dataset=lfsa_ehomp\&lang=en: EUROSTAT. https://appsso.eurostat.ec.europa.eu/nui/show.do?dataset=lfsa_ehomp\&lang=en 
Fana, M., Milasi, S., Napierala, J., Fernandez-Macias, E., \& Vázquez, I. G. (2020). Telework, work organisation and job quality during the COVID-19 crisis: a qualitative study. N. European Commision Joint Research Centre (JRC) Working Papers. http://hdl.handle.net/10419/231343

Fox, W. M. (1995). Sociotechnical system principles and guidelines: past and present. The Journal of applied behavioral science, 31(1), 91-105. https://doi.org/10.1177/0021886395311009

Grant, C. A., Wallace, L. M., \& Spurgeon, P. C. (2013). An exploration of the psychological factors affecting remote e-worker's job effectiveness, well-being and work-life balance. Employee Relations, 35(5), 527-546. https://doi.org/10.1108/ER-08-2012-0059

Grant, C. A., Wallace, L. M., Spurgeon, P. C., Tramontano, C., \& Charalampous, M. (2019). Construction and initial validation of the E-Work Life Scale to measure remote e-working. Employee Relations, 41(1), 16-33. https://doi.org/10.1108/ER-09-2017-0229

Harrington, E., \& Emanuel, N. (2020). Working Remotely? Selection, Treatment, and Market Provision of Remote Work Harvard University Working paper https://scholar.harvard.edu/eharrington/publications/working-remotely-selection-treatmentand-market-provision-remote-work

Ipsen, C., Kirchner, K., \& Hansen, J. P. (2020). Experiences of working from home in times of covid19 International survey conducted the first months of the national lockdowns March-May 2020. Technical University of Denmark (DTU) Internal Report 2020. https://orbit.dtu.dk/en/publications/experiences-of-working-from-home-in-times-of-covid-19internation

Ipsen, C., van Veldhoven, M., Kirchner, K., \& Hansen, J. P. (2021). Six key advantages and disadvantages of working from home in Europe during COVID-19. International Journal of Environmental Research and Public Health, 18(4), 1826. https://doi.org/10.3390/ijerph18041826

ISO. (2019). ISO 9241-210 Ergonomics of human-system interaction - Part 210: Human-centred design for interactive systems. Brussels, BE: European Committee for Standardization. https://www.iso.org/standard/77520.html 
Koopmans, L., Bernaards, C., Hildebrandt, V., van Buuren, S., Van der Beek, A. J., \& de Vet, H. C. (2013). Development of an individual work performance questionnaire. International journal of productivity and performance management, 62(1), 6-28. https://doi.org/10.1108/17410401311285273

Koopmans, L., Bernaards, C. M., Hildebrandt, V. H., de Vet, H. C., \& van der Beek, A. J. (2014). Measuring individual work performance: Identifying and selecting indicators. Work, 48(2), 229-238. https://doi.org/10.3233/WOR-131659

Kröll, C., \& Nüesch, S. (2019). The effects of flexible work practices on employee attitudes: evidence from a large-scale panel study in Germany. The International Journal of Human Resource Management, 30(9), 1505-1525. https://doi.org/10.1080/09585192.2017.1289548

Langvik, E., Karlsen, H. R., Saksvik-Lehouillier, I., \& Sørengaard, T. A. (2021). Police employees working from home during COVID-19 lockdown: Those with higher score on extraversion miss their colleagues more and are more likely to socialize with colleagues outside work. Personality and Individual Differences, 179, Article 110924.

https://doi.org/10.1016/j.paid.2021.110924

Liberati, A., Altman, D. G., Tetzlaff, J., Mulrow, C., Gøtzsche, P. C., Ioannidis, J. P. A., Clarke, M., Devereaux, P. J., Kleijnen, J., \& Moher, D. (2009). The PRISMA statement for reporting systematic reviews and meta-analyses of studies that evaluate healthcare interventions: explanation and elaboration. $B M J, 339$, b2700. https://doi.org/10.1136/bmj.b2700

Lund, S., Madgavkar, A., Manyika, J., Smit, S., Ellingrud, K., Meaney, M., \& Robinson, O. (2021). The future of work after COVID-19. McKinsey Global Institute. https://www.mckinsey.com/featured-insights/future-of-work/the-future-of-work-after-covid19

Malik, A., Rosenberger, P. J., Fitzgerald, M., \& Houlcroft, L. (2016). Factors affecting smart working: evidence from Australia. International Journal of Manpower, 37(6), 1042-1066. https://doi.org/10.1108/ijm-12-2015-0225

Mallia, K. L., \& Ferris, S. P. (2000). Telework: A consideration of its impact on individuals and organizations. Electronic Journal of Communication, 10(3), 4. 
Maruyama, T., Hopkinson, P. G., \& James, P. W. (2009). A multivariate analysis of work-life balance outcomes from a large-scale telework programme. New Technology, Work and Employment, 24(1), 76-88. https://doi.org/10.1111/j.1468-005X.2008.00219.x

Mazzucchelli, S. (2017). Flexibility and work-family balance: a win-win solution for companies? The case of Italy. International Review of Sociology-Revue Internationale De Sociologie, 27(3), 436-456. https://doi.org/10.1080/03906701.2017.1377411

Molino, M., Ingusci, E., Signore, F., Manuti, A., Giancaspro, M. L., Russo, V., Zito, M., \& Cortese, C. G. (2020). Wellbeing Costs of Technology Use during Covid-19 Remote Working: An Investigation Using the Italian Translation of the Technostress Creators Scale. Sustainability, 12(15), 20, Article 5911. https://doi.org/10.3390/su12155911

Moretti, A., Menna, F., Aulicino, M., Paoletta, M., Liguori, S., \& Iolascon, G. (2020). Characterization of home working population during covid-19 emergency: A cross-sectional analysis. International Journal of Environmental Research and Public Health, 17(17), 1-13, Article 6284. https://doi.org/10.3390/ijerph17176284

Morgan, S. J., \& Symon, G. (2002). Computer-mediated communication and remote management: integration or isolation? Social Science Computer Review, 20(3), 302-311. https://doi.org/10.1177/089443930202000307

Munn, Z., Peters, M. D., Stern, C., Tufanaru, C., McArthur, A., \& Aromataris, E. (2018). Systematic review or scoping review? Guidance for authors when choosing between a systematic or scoping review approach. BMC medical research methodology, 18(1), 1-7. https://doi.org/10.1186/s12874-018-0611-x

Nakrošienė, A., Bučiūnienė, I., \& Goštautaitė, B. (2019). Working from home: characteristics and outcomes of telework. International Journal of Manpower, 40(1), 87-101. https://doi.org/10.1108/IJM-07-2017-0172

Nansen, B., Arnold, M., Gibbs, M., \& Davis, H. (2010). Time, space and technology in the workinghome: an unsettled nexus. New Technology Work and Employment, 25(2), 136-153. https://doi.org/10.1111/j.1468-005X.2010.00244.x 
Negulescu, O. H., \& Doval, E. (2021). Ergonomics and time management in remote working from home. Acta Technica Napocensis Series-Applied Mathematics Mechanics and Engineering, 64(SI 1), 99-108. https://atna-mam.utcluj.ro/index.php/Acta/article/view/1500

Prihadi, K. D., Lim, E. S. Z., Chan, K. C., Lee, S. M. H., \& Ridwan, A. (2021). Efficacy of working from home among urban professionals in Malaysia during the pandemic: The robust predictive role of mattering. International Journal of Public Health Science, 10(1), 215-220. https://doi.org/10.11591/ijphs.v10i1.20736

Raffaele, C., \& Connell, J. (2016). Telecommuting and co-working communities: what are the implications for individual and organizational flexibility? In Sushil, J. Connell, \& J. Burgess (Eds.), Flexible Work Organizations: The Challenges of Capacity Building in Asia (pp. 2135). Springer. https://doi.org/10.1007/978-81-322-2834-9_2

Ragu-Nathan, T., Tarafdar, M., Ragu-Nathan, B. S., \& Tu, Q. (2008). The consequences of technostress for end users in organizations: Conceptual development and empirical validation. Information Systems Research, 19(4), 417-433. https://doi.org/10.1287/isre.1070.0165

Raguseo, E., Neirotti, P., Paolucci, E., Gastaldi, L., Corso, M., \& Martini, A. (2014). Towards a Smarter Work? Unpacking Complementarities between ICT Adoption, Human Resource Practices and Office Layout [Paper presentation]. The 9th International Forum on Knowledge Asset Dynamics, Matera. https://www.webofscience.com/wos/woscc/fullrecord/WOS:000357262303029?SID=D3SpIztfkHVr7IzONnY

Rajanen, M., \& Rajanen, D. (2020). Usability as Speculum Mundi: A Core Concept in Socio-technical Systems Development. Complex Systems Informatics and Modeling Quarterly, 129(22), 4959. https://doi.org/10.7250/csimq.2020-22.04

Renu, N. (2021). Technological advancement in the era of COVID-19. SAGE Open Medicine, 9, 20503121211000912. https://doi.org/10.1177/20503121211000912

Riva, G., Wiederhold, B. K., \& Mantovani, F. (2021). Surviving COVID-19: The Neuroscience of Smart Working and Distance Learning. Cyberpsychology, Behavior, and Social Networking, 24(2), 79-85. https://doi.org/10.1089/cyber.2021.0009 
Schade, H. M., Digutsch, J., Kleinsorge, T., \& Fan, Y. (2021). Having to work from home: Basic needs, well-being, and motivation. International Journal of Environmental Research and Public Health, 18(10), Article 5149. https://doi.org/10.3390/ijerph18105149

Schaufeli, W. B., Bakker, A. B., \& Salanova, M. (2006). The measurement of work engagement with a short questionnaire: A cross-national study. Educational and psychological measurement, 66(4), 701-716. https://doi.org/10.1177/0013164405282471

Schaufeli, W. B., Shimazu, A., Hakanen, J., Salanova, M., \& De Witte, H. (2017). An ultra-short measure for work engagement. European Journal of Psychological Assessment, 35(4), 577 591. https://doi.org/10.1027/1015-5759/a000430

Shao, Y., Fang, Y., Wang, M., Chang, C.-H. D., \& Wang, L. (2021). Making daily decisions to work from home or to work in the office: The impacts of daily work-and COVID-related stressors on next-day work location. Journal of Applied Psychology, 106(6), 825-838. https://doi.org/10.1037/ap10000929

Stern, P. N. (1980). Grounded theory methodology: Its uses and processes. Image, 12(1), 20-23. https://doi.org/10.1111/j.1547-5069.1980.tb01455.x.

Tagliaro, C., \& Ciaramella, A. (2016). Experiencing smart working: a case study on workplace change management in Italy. Journal of Corporate Real Estate, 18(3), 194-208. https://doi.org/10.1108/jcre-10-2015-0034

Tricco, A. C., Lillie, E., Zarin, W., O'Brien, K. K., Colquhoun, H., Levac, D., Moher, D., Peters, M. D., Horsley, T., \& Weeks, L. (2018). PRISMA extension for scoping reviews (PRISMA-ScR): checklist and explanation. Annals of internal medicine, 169(7), 467-473. https://doi.org/10.7326/M18-0850.

Troup, C., \& Rose, J. (2012). Working from home: Do formal or informal telework arrangements provide better work-family outcomes? Community, Work and Family, 15(4), 471-486. https://doi.org/10.1080/13668803.2012.724220

Tustin, D. H. (2014). Telecommuting academics within an open distance education environment of South Africa: More content, productive, and healthy? International Review of Research in Open and Distance Learning, 15(3), 185-214. https://doi.org/10.19173/irrodl.v15i3.1770 
United Nations. (2020). Education During COVID-19 and Beyond [Policy Brief]. UN Executive

Office of the Secretary-General (EOSG) Policy Briefs and Papers. https://doi.org/10.18356/21e7d903-en

van der Lippe, T., \& Lippényi, Z. (2020). Co-workers working from home and individual and team performance. New Technology, Work and Employment, 35(1), 60-79. https://doi.org/10.1111/ntwe.12153

Wang, B., Liu, Y., Qian, J., \& Parker, S. K. (2021). Achieving Effective Remote Working During the COVID-19 Pandemic: A Work Design Perspective. Applied Psychology, 70(1), 16-59. https://doi.org/https://doi.org/10.1111/apps.12290

Wang, W., \& Ronen, S. (2011). Employee loyalty and telecommuting. World Academy of Science, Engineering and Technology, 77, 687-689. https://doi.org/10.5281/zenodo.1330513

Zhang, C., Yu, M. C., \& Marin, S. (2021). Exploring public sentiment on enforced remote work during COVID-19. Journal of Applied Psychology, 106(6), 797-810. https://doi.org/10.1037/ap10000933 


\section{Supplementary material 1}

Scopus Search 5 May 2021

( TITLE-ABS-KEY ( "Remote working" ) OR TITLE-ABS-KEY ( "Smart working" ) OR TITLEABS-KEY ("working from home" ) AND TITLE-ABS-KEY ("Experience" ) OR TITLE-ABSKEY ( "Perceived quality" ) OR TITLE-ABS-KEY ( "Perceived satisfaction" ) OR TITLE-ABSKEY ( "satisfaction" ) ) AND ( LIMIT-TO ( PUBSTAGE, "final" ) ) AND ( LIMITTO ( DOCTYPE, "ar" ) OR LIMIT-TO ( DOCTYPE, "cp" ) OR LIMITTO ( DOCTYPE, "ch" ) ) AND ( LIMIT-TO ( PUBYEAR, 2021 ) OR LIMITTO ( PUBYEAR, 2020 ) OR LIMIT-TO ( PUBYEAR, 2019) OR LIMITTO ( PUBYEAR, 2018 ) OR LIMIT-TO ( PUBYEAR, 2017 ) OR LIMITTO ( PUBYEAR, 2016 ) OR LIMIT-TO ( PUBYEAR, 2015 ) OR LIMITTO ( PUBYEAR , 2014 ) OR LIMIT-TO ( PUBYEAR, 2012 ) OR LIMITTO ( PUBYEAR, 2011 ) OR LIMIT-TO ( PUBYEAR, 2010 )) AND ( LIMITTO ( LANGUAGE , "English" ) )

Web of Science 5 May 2021

"Remote working" (Title) OR "smart working" (Title) OR "working from home"(Title) AND "experience"(Topic) AND "perceived quality"(Topic) AND "perceived satisfaction"(Topic) AND "satisfaction"

Document type: Articles or Proceedings papers or Book Review

Language: English 


\section{Supplementary material 2}

Variables collected and the modalities of data collection for each record. The modalities are reported according to the following four categories: i) descriptive variables - e.g., data about participants individual characteristics used for descriptive or data analysis purposes; ii) qualitative items, iii) items from adapted scales, and iv) validated (standardized) scales and indexes used to measure the variables. Moreover, the following aspects are detailed if reported by the authors: number and description of the items, and reliability of the tools.

\begin{tabular}{|c|c|c|}
\hline Study ID & Variables investigated & Measures/Scales for the investigation \\
\hline 1 & $\begin{array}{l}\text { - Work and family } \\
\text { conflict } \\
\text { - Management support } \\
\text { and influence }\end{array}$ & $\begin{array}{l}\text { DESCRIPTIVE: Sex, Age; QUALITATIVE items: } 1 \\
\text { item Extra home hours, } 1 \text { item to assess Days worked at } \\
\text { home, } 6 \text { items on Work social support by family; } \\
\text { ADAPTED - reliability not reported for the items } \\
\text { adapted: Organizational support } 4 \text { items from } \\
\text { Eisenberger et al. (1986). Manager style using } 9 \text { items } \\
\text { of the Multifactor Leadership Questionnaire (Muenjohn } \\
\& \text { Armstrong, 2008) adapted from (Frone et al., 1992) } \\
\text { and (Carlson et al., 2000) }\end{array}$ \\
\hline 2 & $\begin{array}{l}\text { Management of time } \\
\text { and spatial } \\
\text { constraints and } \\
\text { conflicts }\end{array}$ & $\begin{array}{l}\text { DESCRIPTIVE: Age, gender; QUALITATIVE Items: } \\
\text { not reported }\end{array}$ \\
\hline 3 & $\begin{array}{l}\text { - Loyalty toward } \\
\text { company, peers and } \\
\text { role } \\
\text { - Job satisfaction }\end{array}$ & - \\
\hline
\end{tabular}




\begin{tabular}{|c|c|c|}
\hline 4 & $\begin{array}{l}\text { - Living situation, } \\
\text { including time spent } \\
\text { on childcare } \\
\text { (average hours per } \\
\text { week) and } \\
\text { distribution of work } \\
\text { and home tasks } \\
\text { - Performance } \\
\text { - Job satisfaction }\end{array}$ & $\begin{array}{l}\text { DESCRIPTIVE: Age, gender, type of work/role, } \\
\text { full/part-time. QUALITATIVE: work-life balance } \\
\text { modeled by the living situation with items regarding the } \\
\text { number of children or others to take care, and sharing } \\
\text { duty. Own made additional items regarding satisfaction } \\
\text { with taking care of children and shared duty at home. } \\
\text { The reasoning behind items and reliability not reported. } \\
\text { STANDARDISED: a work attitude scale of } 14 \text { items } \\
\text { (reliability: .87) was used to measure (Warr et al., 1979). }\end{array}$ \\
\hline 5 & $\begin{array}{l}\text { - Individual task and } \\
\text { contextual } \\
\text { performance } \\
\text { - Counterproductive } \\
\text { behavior }\end{array}$ & $\begin{array}{l}\text { DESCRIPTIVE: Age, gender, education. } \\
\text { STANDARDISED: Proposed and tested a new version } \\
\text { of a scale to assess Individual work performance (IWPS) } \\
\text { composed of } 14 \text { items (reliability: between } 0.7 \text { and } 0.8 \text { ) } \\
\text { including items regarding counterproductive behaviors }\end{array}$ \\
\hline 6 & $\begin{array}{l}\text { - Individual task and } \\
\text { contextual } \\
\text { performance } \\
\text { - Counterproductive } \\
\text { behavior }\end{array}$ & $\begin{array}{l}\text { DESCRIPTIVE: Age, gender, education, type of work, } \\
\text { and type of company. List of } 317 \text { indicators of work } \\
\text { performances resulted from literature, survey, and } \\
\text { interview. A second survey was used to define a final } \\
\text { list of } 23 \text { indicators of work performance including } \\
\text { items regarding counterproductive behaviors. }\end{array}$ \\
\hline 7 & $\begin{array}{l}\text { - Flexibility in the job } \\
\text { - Management of } \\
\text { work-life balance } \\
\text { - Layout and } \\
\text { technology elements }\end{array}$ & $\begin{array}{l}\text { QUALITATIVE: The survey used } 7 \text { items (not reported) } \\
\text { with multiple options were used to survey Information } \\
\text { about Layout, ICT, management style, and flexibility. } \\
\text { Interviews items investigating aspects regarding work- } \\
\text { life balance and management of innovation were not } \\
\text { reported. }\end{array}$ \\
\hline
\end{tabular}




\begin{tabular}{|c|c|c|}
\hline & $\begin{array}{l}\text { - Innovativeness of } \\
\text { management }\end{array}$ & \\
\hline 8 & $\begin{array}{l}\text { - Advantages and } \\
\text { disadvantages of } \\
\text { WFH } \\
\text { - Job satisfaction } \\
\text { - Commuting duty and } \\
\text { flexibility of the job } \\
\text { - Work-life balance } \\
\text { aspects e.g., more } \\
\text { time with family and } \\
\text { better management } \\
\text { of time } \\
\text { Well-being aspects } \\
\text { e.g., improved } \\
\text { quality of life }\end{array}$ & $\begin{array}{l}\text { DESCRIPTIVE: Unclear collection of demographic } \\
\text { data. QUALITATIVE: Proposed an own made set of } \\
\text { items (list of items is not provided) with reliability from } \\
0.75 \text { to } 0.98 \text {. The reasoning behind the items is not } \\
\text { provided or discussed. }\end{array}$ \\
\hline 9 & $\begin{array}{l}\text { - Performance } \\
\text { - Commuting duty } \\
\text { - Work-life situation } \\
\text { - Satisfaction (life and } \\
\text { - Exhaustion } \\
\text { - Attitude toward } \\
\text { work }\end{array}$ & $\begin{array}{l}\text { DESCRIPTIVE: Age, gender, education income, } \\
\text { monthly expenses with open questions were used for the } \\
\text { profiling. QUALITATIVE: Data about the daily } \\
\text { commute in minutes and living situation are used to } \\
\text { model work-life balance. STANDARDISED: Indexes } \\
\text { were used to assess performance. Positive and Negative } \\
\text { Affect Schedule PANAS composed of } 16 \text { items } \\
\text { (reliability: not reported) was used to assess attitudes } \\
\text { (Clark \& Tellegen, 1988). ADAPTED: Adapted from }\end{array}$ \\
\hline
\end{tabular}




\begin{tabular}{|c|c|c|}
\hline & & $\begin{array}{l}\text { the Burnout Inventory (Maslach \& Jackson, 1981) } 6 \\
\text { items were used to estimate work exhaustion intended } \\
\text { here as an indirect measure of satisfaction (reliability } \\
\text { unclear). A post-survey was also implemented, to further } \\
\text { explore WFH, but items are not explained. }\end{array}$ \\
\hline 10 & $\begin{array}{l}\text { - Perceived value of } \\
\text { WFH } \\
\text { - Family and work } \\
\text { values and balance } \\
\text { - Favorable attitude } \\
\text { toward WFH } \\
\text { Motivational factors } \\
\text { (intentions) } \\
\text { Organization of the } \\
\text { work environment } \\
\text { and job position }\end{array}$ & $\begin{array}{l}\text { DESCRIPTIVE: Age, gender, gross annual income, } \\
\text { weekly hours worked, education level completed, firm } \\
\text { size (number of employees). QUALITATIVE: } \\
\text { Qualitative items were used to profile the type of } \\
\text { organization and the job position about nature of the } \\
\text { firm (e.g. private or state enterprise), who would be } \\
\text { paying the user's WFH cost, and if a formal or informal } \\
\text { policy covering flexible work was in place at the } \\
\text { respondent's organization. Three items measured work } \\
\text { commute - home-work distance (kilometers), time } \\
\text { (minutes), and weekly cost (dollars) - and two items } \\
\text { tapped SWH commute - home-WFH distance } \\
\text { (kilometers) and time (minutes). ADAPTED: } 20 \text { own } \\
\text { made items based on previous literature reliability of } \\
\text { from } 0.82 \text { to } 0.94 \text {. The complete list of items is only } \\
\text { partially provided. Items regarding the perceived value } \\
\text { of WHF, family, and work value were adapted from } \\
\text { multiple sources (Carlson et al., } 2015 \text {; Sanchez et al., } \\
\text { items regarding the intention to use WFH came from }\end{array}$ \\
\hline
\end{tabular}




\begin{tabular}{|c|c|c|}
\hline & & $\begin{array}{l}\text { multiple resources (Ajzen, 1991, 2001; Fishbein \& } \\
\text { Ajzen, 1972). }\end{array}$ \\
\hline 11 & $\begin{array}{l}\text { - Family-work } \\
\text { reconciliation } \\
\text { - Flexibility } \\
\text { - Lack of autonomy } \\
\text { and support } \\
\text { - Advantages and } \\
\text { disadvantages }\end{array}$ & $\begin{array}{l}\text { DESCRIPTIVE: Age, gender, education, Living } \\
\text { situation, Size of the town of residence, Place of work, } \\
\text { Travel time to work, Employment status, Problems } \\
\text { making ends meet, Household, work and care load, } \\
\text { Sharing tasks within the family, Further problems. Items } \\
\text { are not reported. QUALITATIVE: Proposed } 26 \text { own } \\
\text { made items to measure subjective benefit from WFH, } \\
\text { this includes work-life balance but the main focus was } \\
\text { on subjective gain. Items were based on previous } \\
\text { literature, items and reliability are not reported }\end{array}$ \\
\hline 12 & $\begin{array}{l}\text { - Engagement } \\
\text { - Organizational } \\
\text { - Exchange with } \\
\text { - Social isolation }\end{array}$ & $\begin{array}{l}\text { DESCRIPTIVE: Sex, Age, Education, Supervisory } \\
\text { position or not; Qualitative items: } 1 \text { item daily activity } \\
\text { from home; ADAPTED: } 3 \text { items about exchanges with } \\
\text { management (Scandura \& Graen, 1984), } 4 \text { items about } \\
\text { Organizational commitment (Allen \& Meyer, 1990), } 9 \\
\text { items work engagement, adapted from Schaufeli et al. } \\
\text { (2006). } 4 \text { items regarding professional isolation, adapted } \\
\text { from(Golden et al., 2008). Items reported in } \\
\text { supplementary material }\end{array}$ \\
\hline
\end{tabular}




\begin{tabular}{|c|c|c|}
\hline 13 & $\begin{array}{l}\text { - Work-life } \\
\text { interference } \\
\text { - Flexibility } \\
\text { - Well-being } \\
\text { - Organizational } \\
\text { aspects that affect } \\
\text { WFH }\end{array}$ & $\begin{array}{l}\text { DESCRIPTIVE: Age, gender, role, type of company. } \\
\text { STANDARDISED: eWorklife Scale (EWL) validation } \\
\text { composed of } 17 \text { items }\end{array}$ \\
\hline 14 & $\begin{array}{l}\text { - Need to } \\
\text { communicate with } \\
\text { - Colleagues } \\
\text { work-life balance } \\
\text { e.g., taking care of } \\
\text { family, WFH for } \\
\text { sickness } \\
\text { - Suitability of } \\
\text { working space at } \\
\text { home; } \\
\text { - Supervisor's trust } \\
\text { and support } \\
\text { organization's }\end{array}$ & $\begin{array}{l}\text { DESCRIPTIVE: Age (in years) and marital status/ living } \\
\text { situation. } \\
\text { QUALITATIVE: qualitative items were used to profile } \\
\text { the organizational aspects such as Organizational tenure } \\
\text { (in years) and type of work flexibility. Moreover, } 16 \\
\text { own made items regarding ten key factors and carriers } \\
\text { opportunities were asked but the reasoning behind the } \\
\text { items and reliability are not reported. }\end{array}$ \\
\hline
\end{tabular}




\begin{tabular}{|c|c|c|}
\hline & $\begin{array}{l}\text { - Time management } \\
\text { and work home in } \\
\text { - Satisfaction } \\
\text { - Advantages of WFH } \\
\text { - Self-reported } \\
\text { productivity }\end{array}$ & \\
\hline 15 & $\begin{array}{l}\text { - Flexibility } \\
\text { - Freedom of } \\
\text { managing time and } \\
\text { work activities } \\
\text { - Subjective and } \\
\text { objective } \\
\text { productivity } \\
\text { - Well-being } \\
\text { - Sork-life balance } \\
\text { Satisfaction }\end{array}$ & $\begin{array}{l}\text { DESCRIPTIVE: age, gender, education, disability, } \\
\text { living situation, work activity per day in minutes. } \\
\text { STANDARDARDISED: Objective productivity } \\
\text { reported by the workers' supervisor. QUALITATIVE } \\
69 \text { items partially own made and for the well-being, } \\
\text { some items were adapted from: British Household Panel } \\
\text { Survey regarding well-being (Taylor et al., 1993). The } \\
\text { reliability of the items was not reported. To assess } \\
\text { subjective productivity, satisfaction, well-being } \\
\text { perceived freedom, work-life balance }\end{array}$ \\
\hline 16 & $\begin{array}{l}\text { - Job satisfaction } \\
\text { - Improved work-life } \\
\text { balance } \\
\text { - Workers personality } \\
\text { - Job characteristics } \\
\text { and organizational } \\
\text { aspects }\end{array}$ & $\begin{array}{l}\text { DESCRIPTIVE: Age, gender, education, nationality, } \\
\text { tolerance to risk, type of job (permanent or not), and } \\
\text { type of role, Working hours per week, Training in the } \\
\text { last weeks, income. ADAPTED: } 23 \text { own-made items to } \\
\text { assess work-life balance, satisfaction job type and } \\
\text { communication in the workplace, issues associated with } \\
\text { the work and the company. Items are reported to be } \\
\text { connected to previous literature (Dex \& Bond, 2005; }\end{array}$ \\
\hline
\end{tabular}




\begin{tabular}{|c|c|c|}
\hline & $\begin{array}{l}\text { - Commitment } \\
\text { information } \\
\text { - Collegiality of } \\
\text { organization }\end{array}$ & $\begin{array}{l}\text { Song \& Gao, 2020), but the connection is not clear, } \\
\text { items are not reported and reliability is not presented. } \\
\text { STANDARDISED: The Big5 personality test used is not } \\
\text { reported, nor referenced. }\end{array}$ \\
\hline 17 & $\begin{array}{l}\text { - Individual } \\
\text { advantages and } \\
\text { disadvantages of } \\
\text { WHF }\end{array}$ & $\begin{array}{l}\text { DESCRIPTIVE: Age, gender, education, type of work, } \\
\text { number of weekly days (Not all reported). } \\
\text { STANDARDISED: } 23 \text { items developed based on (Ipsen } \\
\text { et al., 2020). Items and reliability are not discussed in } \\
\text { the record. }\end{array}$ \\
\hline 18 & $\begin{array}{l}\text { - Stress } \\
\text { - Exhaustion } \\
\text { - Withdrawal behavior } \\
\text { - Job satisfaction }\end{array}$ & $\begin{array}{l}\text { DESCRIPTIVE: Age, gender, nationality, sleep quality. } \\
\text { ADAPTED: } 18 \text { items based on previous literature. Items } \\
\text { are partially provided but the reliability of the items was } \\
\text { not discussed. Specifically, items were adapted to } \\
\text { measure General task interdependence (Pearce \& } \\
\text { Gregersen, 1991) to model task complexity, from the } \\
\text { supportive behavior scale (Trougakos et al., 2015) and } \\
\text { from the disruptive work events scale (Zohar et al., } \\
\text { 2003) to model need for support, and work withdrawal } \\
\text { behavior scale (Spector et al., 2006) to ascertain aspects } \\
\text { related to the relationship with work activity. Moreover, } \\
\text { exhaustion items were adapted from the previous scale } \\
\text { (Maslach \& Jackson, 1981). }\end{array}$ \\
\hline 19 & $\begin{array}{l}\text { - Flexibility of job and } \\
\text { time } \\
\text { - Adaptability of } \\
\text { working space }\end{array}$ & $\begin{array}{l}\text { DESCRIPTIVE: Age, gender, principal occupation, } \\
\text { seniority within the company, Company size, Sector of } \\
\text { activity, Legal status of the company. QUALITATIVE: } \\
\text { A set of } 14 \text { items with different types of options } \\
\text { (dichotomous, multiple options, and five Likert-scale) }\end{array}$ \\
\hline
\end{tabular}




\begin{tabular}{|c|c|c|}
\hline & $\begin{array}{l}\text { organization and } \\
\text { technology } \\
\text { - Job satisfaction } \\
\text { - Increased } \\
\text { productivity and } \\
\text { efficiency } \\
\text { - Interpersonal } \\
\text { relationships } \\
\text { - Personal comfort and } \\
\text { motivation } \\
\text { Management of } \\
\text { working time }\end{array}$ & $\begin{array}{l}\text { about the type of contract flexibility, management of } \\
\text { time, and layout. } 3 \text { own made items about job } \\
\text { satisfaction, degree of salary satisfaction, and degree of } \\
\text { satisfaction regarding working conditions. Items are } \\
\text { reported but the reasoning behind and the validity of the } \\
\text { item is not discussed. }\end{array}$ \\
\hline 20 & $\begin{array}{l}\text { - Productivity } \\
\text { - Management of } \\
\text { - Imprork-life balance } \\
\text { of workers } \\
\text { - Layout of the space } \\
\text { and information and } \\
\text { technology } \\
\text { infrastructure } \\
\text { - Quality of } \\
\text { management and }\end{array}$ & $\begin{array}{l}\text { DESCRIPTIVE: Type of company. QUALITATIVE: } \\
\text { items not reported }\end{array}$ \\
\hline
\end{tabular}




\begin{tabular}{|c|c|c|}
\hline & $\begin{array}{l}\text { organization-related } \\
\text { aspects }\end{array}$ & \\
\hline 21 & $\begin{array}{l}\text { - Advantages and } \\
\text { disadvantages of } \\
\text { WFH }\end{array}$ & $\begin{array}{l}\text { DESCRIPTIVE: Age, gender, education, type of work; } \\
\text { STANDARDISED: } 27 \text { items are discussed and tested to } \\
\text { test the advantages and disadvantages of WFH } \\
\text { (reliability }>0.8 \text { ) }\end{array}$ \\
\hline 22 & $\begin{array}{l}\text { - Improved work-life } \\
\text { balance } \\
\text { - Stress in WFH } \\
\text { - Stress induced by } \\
\text { technology }\end{array}$ & $\begin{array}{l}\text { DESCRIPTIVE: Age, gender, education, type of work; } \\
\text { STANDARDISED: } 11 \text { Items of the Technostress Scale } \\
\text { (Ragu-Nathan et al., 2008) was validated in the context } \\
\text { of WFH (reliability between .81 and .91). The } \\
\text { Copenhagen psychosocial scale (Kristensen et al., 2006) } \\
\text { was used to assess stress (reliability: .86). ADAPTED: } 3 \\
\text { items (Reliability: } 0.85 \text { ) concerning workload were } \\
\text { adapted from literature (Melin et al., 2014). } 3 \text { items were } \\
\text { adapted from literature (De Simone et al., 2018; } \\
\text { Kinnunen et al., 2006)to assess work-family (Reliability: } \\
.90 \text { ). }\end{array}$ \\
\hline 23 & $\begin{array}{l}\text { - Engagement } \\
\text { - Pain } \\
\text { - Stress } \\
\text { - Avoidance } \\
\text { - Flexibility in tasks } \\
\text { - Living situation }\end{array}$ & $\begin{array}{l}\text { DESCRIPTIVE: Age, gender, weight, height, education, } \\
\text { job levels, QUALITATIVE: living situation, remote } \\
\text { working experience, kind of job and its differences from } \\
\text { traditional work ( } 12 \text { items not reported). Moreover, } \\
\text { additional questions about productivity were not } \\
\text { reported. STANDARDISED: } 17 \text { items of the Utrecht } \\
\text { Work Engagement Scale, reliability: .80 -.90 (Schaufeli }\end{array}$ \\
\hline
\end{tabular}




\begin{tabular}{|c|c|c|}
\hline & $\begin{array}{l}\text { - Perceived } \\
\text { productivity } \\
\text { - Advantages and } \\
\text { disadvantages of } \\
\text { WFH }\end{array}$ & $\begin{array}{l}\text { et al., 2006); } 16 \text { items of the Fear Avoidance Beliefs } \\
\text { Questionnaire, reliability:0.8 (Monticone et al., 2012). } \\
\text { ADAPTED: } 4 \text { items from the Brief Pain Inventory } \\
\text { reliability: } 0.75 \text { (Caraceni et al., 1996). } 16 \text { items of the } \\
\text { Fear Avoidance Beliefs Questionnaire, reliability:0.8 } \\
\text { (Monticone et al., 2012). }\end{array}$ \\
\hline 24 & $\begin{array}{l}\text { - Work performance } \\
\text { - Type of WFH } \\
\text { oversight and } \\
\text { collaboration } \\
\text { - Perceived autonomy } \\
\text { - Job satisfaction } \\
\text { - Job demands } \\
\text { - Job position } \\
\text { - Situation at home, } \\
\text { commuting and } \\
\text { work-life balance }\end{array}$ & $\begin{array}{l}\text { DESCRIPTIVE: Age, gender, years of education, type } \\
\text { of work, living situation, commuting time in hours, } \\
\text { amount of work from home per week, time for tenure. } \\
\text { QUALITATIVE: three items multiple choice regarding } \\
\text { the working from home activity in teams or alone. Own } \\
\text { made items to assess productivity and job satisfaction } \\
\text { were are not reported or discussed in terms of reliability. } \\
\text { ADAPTED: Individual work performance scale (IWPS) } \\
\text { but it is not clear how many items they used from this } \\
\text { battery, the reliability was reported equal to .85 } \\
\text { (Koopmans et al., 2013). } 4 \text { items adapted Job Control } \\
\text { Inventory (Karasek Jr, 1979) to assess autonomy } \\
\text { (reliability: .86). } 4 \text { items adapted value commitment } \\
\text { battery (Angle \& Perry, 1981) to assess commitment } \\
\text { (reliability: .75). } 4 \text { items adapted from the Job Content } \\
\text { Questionnaire (Karasek et al., 1998) to assess physical } \\
\text { job demands (reliability: .75). }\end{array}$ \\
\hline 25 & $\begin{array}{l}\text { - Work efficiency } \\
\text { - Well-being }\end{array}$ & $\begin{array}{l}\text { DESCRIPTIVE: Position, type of work, gender, age } \\
\text { group, living situation and the age and the number of } \\
\text { children, need for more efficient work from home. } \\
\text { QUALITATIVE: } 15 \text { efficiency or well-being related }\end{array}$ \\
\hline
\end{tabular}




\begin{tabular}{|c|c|c|}
\hline & $\begin{array}{l}\text { - Living situation and } \\
\text { work-life balance } \\
\text { - Advantages and } \\
\text { disadvantages of } \\
\text { WFH }\end{array}$ & $\begin{array}{l}\text { aspects of work were used to compare advantages and } \\
\text { disadvantages of working from the office and home } \\
\text { based on a (reported) previous pilot study. Two own } \\
\text { made items regarding the ideal time that respondents } \\
\text { want to spend WFH ) and feasibility of working from } \\
\text { home. Items are presented, but the reliability of the } \\
\text { items is not discussed. }\end{array}$ \\
\hline 26 & $\begin{array}{l}\text { - Job satisfaction } \\
\text { - Motivation } \\
\text { - Organizational } \\
\text { - Personal fears and } \\
\text { anxiety }\end{array}$ & $\begin{array}{l}\text { DESCRIPTIVE: Gender, role, years of service, type of } \\
\text { institution. QUALITATIVE: unclear number of items } \\
\text { regarding job motivation, effects of COVID, job } \\
\text { satisfaction, and anxiety organizational issues the role of } \\
\text { reimbursement and training. Reliablity: } 76\end{array}$ \\
\hline 27 & $\begin{array}{l}\text { - Management of } \\
\text { breaks and time } \\
\text { - Management of } \\
\text { elements in the work } \\
\text { space/layout } \\
\text { Positive effect on } \\
\text { well-being }\end{array}$ & - \\
\hline
\end{tabular}




\begin{tabular}{|c|c|c|}
\hline 28 & $\begin{array}{l}\text { - Engagement } \\
\text { - Exhaustion } \\
\text { - Attitude toward the } \\
\text { - } \text { organization } \\
\text { - } \text { pressure/demands } \\
\text { - Work-life conflicts }\end{array}$ & $\begin{array}{l}\text { QUALITATIVE: Workplace. As part of the morning } \\
\text { survey, respondents were asked to indicate whether they } \\
\text { would work from home or at the office on that particular } \\
\text { day. } \\
\text { ADAPTED: } 5 \text { items adapted from the work-family } \\
\text { conflict scale developed by Netemeyer et al. (1996). } \\
\text { Reliability } 0.93 \text {-0.94.; Emotional exhaustion. Adapted } \\
\text { six items from the emotional exhaustion subscale of the } \\
\text { Maslach Burnout Inventory (Maslach \& Jackson, 1981). } \\
\text { Reliability } \alpha \text { was } 0.91 . \text { Positive and negative affect on } \\
\text { the organization. Adapted Positive and Negative Affect } \\
\text { Schedule (PANAS, Watson et al., 1988) Reliability: .69- } \\
\text { 94. Three items to assess work pressure. Adapted from } \\
\text { the five-item workload scale previously used by Pluut et } \\
\text { al. (2018). Reliability was } 0.82 \text {. } \\
\text { STANDARDISED: Work engagement. The nine items } \\
\text { (UWES; Schaufeli et al., 2006) Reliability 0.91 across } \\
\text { days. Time pressure. Items are partially reported }\end{array}$ \\
\hline 29 & $\begin{array}{l}\text { - Engagement } \\
\text { - Work-life balance } \\
\text { - Wob satisfaction } \\
\text { - Demands of and } \\
\text { control over the } \\
\text { work activity } \\
\text { - Peer support }\end{array}$ & $\begin{array}{l}\text { DESCRIPTIVE: Gender, age, education, marital status, } \\
\text { number of children aged less than } 12 \text { years, job } \\
\text { seniority, and commuting. STANDARDISED: } 18 \text { items } \\
\text { from Management Standards Indicator Tool were } \\
\text { proposed in its Italian version, the reliability was } \\
\text { indicated between . } 79 \text { and .9. However, the validation } \\
\text { study of this version is not reported. } 3 \text { items, from Ultra- } \\
\text { Short Measure for Work Engagement (Schaufeli et al., } \\
\text { 2017) were used to assess engagement (reliability: .71 - }\end{array}$ \\
\hline
\end{tabular}




\begin{tabular}{|c|c|}
\hline $\begin{array}{l}\text { - Management support } \\
\text { - Rules and changes at } \\
\text { the organizational } \\
\text { level }\end{array}$ & $\begin{array}{l}\text {.78). ADAPTED: } 1 \text { item based on the World Health } \\
\text { Organization index (Topp et al., 2015) was used to } \\
\text { assess well-being (reliability .89 -.90). } 1 \text { item from } \\
\text { literature (Cortese \& Quaglino, 2006) was used to assess } \\
\text { satisfaction. QUALITATIVE: } 1 \text { Own made item was } \\
\text { used to assess overall satisfaction towards the smart } \\
\text { working experience. } 4 \text { own made items were used to } \\
\text { assess the work-life balance }\end{array}$ \\
\hline $\begin{array}{l}\text { - Job satisfaction } \\
\text { - Advantages and } \\
\text { disadvantages of } \\
\text { WFH } \\
\text { - Perceived work-life } \\
\text { balance } \\
\text { - Perceived work } \\
\text { - Perficiency } \\
\text { - Home office } \\
\text { overwork } \\
\text { constraints } \\
\text { Work uncertainties } \\
\text { Inadequate tools }\end{array}$ & $\begin{array}{l}\text { DESCRIPTIVE: Gender, age, education, nationality. } \\
\text { STANDARDISED: } 27 \text { items tested and presented with } \\
\text { reliability from } 0.55 \text { to } 0.72 \text {, items exclusion is } \\
\text { discussed composing a solution with } 23 \text { items to assess } \\
\text { advantages and disadvantages in WFH. The reliability of } \\
\text { th23 items solution was not discussed. }\end{array}$ \\
\hline $\begin{array}{l}\text { - Personality } \\
\text { - Job satisfaction } \\
\text { - Stress }\end{array}$ & $\begin{array}{l}\text { DESCRIPTIVE: Age group, gender, work } \\
\text { situation/flexibility, living situation. STANDARDISED: } \\
\text { Big Five model of the personality of } 20 \text { items ((John \& }\end{array}$ \\
\hline
\end{tabular}




\begin{tabular}{|c|c|}
\hline $\begin{array}{l}\text { - Socialization needs } \\
\text { - Type of flexibility }\end{array}$ & $\begin{array}{l}\text { Srivastava, 1999). ADAPTED: } 1 \text { item associated with } \\
\text { stress (Elo et al., 2003). QUALITATIVE: } 2 \text { items own } \\
\text { made regarding socialization and needs. The validity of } \\
\text { the items and their adaptation were not discussed }\end{array}$ \\
\hline $\begin{array}{l}\text { - Time management } \\
\text { - Space organization, } \\
\text { setup and } \\
\text { management }\end{array}$ & - \\
\hline $\begin{array}{l}\text { - Mattering } \\
\text { - Self-esteem } \\
\text { - Extraversion } \\
\text { - Work self-efficacy }\end{array}$ & $\begin{array}{l}\text { DESCRIPTIVE: Age, gender, nationality, occupation. } \\
\text { Origin of the items is reported, but it is unclear how } \\
\text { items were modified and if all the original items were } \\
\text { used. ADAPTED: Authors used: the State Self-Esteem } \\
\text { Scale, reliability:.73-.81 (Heatherton \& Polivy, 1991). } \\
\text { General Mattering Scale, reliability:.82 - .92 (Marcus \& } \\
\text { Rosenberg, 1987). Work self-efficacy was measured } \\
\text { using items from the Remote Work Self Efficacy } \\
\text { measure, reliability:.84 (Staples et al., 1999). } \\
\text { STANDARDISED: Extraversion scale of Big Five } \\
\text { Inventory (John \& Srivastava, 1999). }\end{array}$ \\
\hline $\begin{array}{l}\text { - Work-related basic } \\
\text { - Joeds satisfaction } \\
\text { - Autonomy and } \\
\text { oversight } \\
\text { - Support by } \\
\text { colleagues }\end{array}$ & $\begin{array}{l}\text { DESCRIPTIVE: Gender, age, Qualitative: items } \\
\text { regarding the type of flexibility, household size, working } \\
\text { average hours per week, years on the work, } \\
\text { appropriateness of work at home, living situation, and } \\
\text { home duties. STANDARDISED: } 23 \text { items of the work- } \\
\text { Related Basic Needs satisfaction scale, reliability: .81 - } \\
.85 \text { (Van den Broeck et al., 2010). The } 20 \text { items PANAS }\end{array}$ \\
\hline
\end{tabular}




\begin{tabular}{|c|c|c|}
\hline & $\begin{array}{l}\text { - Well-being and } \\
\text { exhaustion } \\
\text { - Tendency to } \\
\text { reappraise } \\
\text { - Detachment from } \\
\text { - Fork } \\
\text { - Wow of the work } \\
\text { Work engagement }\end{array}$ & $\begin{array}{l}\text { (Watson et al., 1988) was used to assess attitude and } \\
\text { detachment together with } 4 \text { items from the Recovery } \\
\text { Experience Questionnaire (Sonnentag \& Fritz, 2007). } 4 \\
\text { items were used to capture the flow of working from the } \\
\text { flow short scale (Rheinberg et al., 2003). Work } \\
\text { Engagement was assessed by the } 9 \text { items version of the } \\
\text { Utrecht Work Engagement questionnaire, reliability: . } 80 \\
\text {-.90 (Schaufeli et al., 2006). } 6 \text { items own made items on } \\
\text { perceived clarity of the work (reliability not reported) }\end{array}$ \\
\hline
\end{tabular}

\section{References of supplementary material 2}

Ajzen, I. (1991). The theory of planned behavior. Organizational behavior and human decision processes, 50(2), 179-211. https://doi.org/10.1016/0749-5978(91)90020-T

Ajzen, I. (2001). Nature and operation of attitudes. Annual review of psychology, 52(1), 27-58. https://doi.org/10.1146/annurev.psych.52.1.27

Allen, N. J., \& Meyer, J. P. (1990). The measurement and antecedents of affective, continuance and normative commitment to the organization. Journal of occupational Psychology, 63(1), 1-18. https://doi.org/10.1111/j.2044-8325.1990.tb00506.x

Angle, H. L., \& Perry, J. L. (1981). An empirical assessment of organizational commitment and organizational effectiveness. Administrative science quarterly, 26(1), 1-14. https://doi.org/10.2307/2392596

Caraceni, A., Mendoza, T. R., Mencaglia, E., Baratella, C., Edwards, K., Forjaz, M. J., Martini, C., Serlin, R. C., De Conno, F., \& Cleeland, C. S. (1996). A validation study of an Italian version of the Brief Pain Inventory (Breve Questionario per la Valutazione del Dolore). Pain, 65(1), 87-92. https://doi.org/10.1016/0304-3959(95)00156-5 
Carlson, D. S., Kacmar, K. M., \& Williams, L. J. (2000). Construction and initial validation of a multidimensional measure of work-family conflict. Journal of vocational behavior, 56(2), 249-276. https://doi.org/10.1006/jvbe.1999.1713

Carlson, J., Rosenberger III, P. J., \& Rahman, M. M. (2015). Cultivating group-oriented travel behaviour to major events: assessing the importance of customer-perceived value, enduring event involvement and attitude towards the host destination. Journal of marketing management, 31(9-10), 1065-1089. https://doi.org/10.1080/0267257X.2015.1035309

Clark, L. A., \& Tellegen, A. (1988). Development and validation of brief measures of positive and negative affect: The PANAS scales. Journal of personality and social psychology, 54(6), 1063-1070. https://doi.org/10.1037//0022-3514.54.6.1063

Cortese, C. G., \& Quaglino, G. P. (2006). The measurement of job satisfaction in organizations: A comparison between a facet scale and a single-item measure. TPM-Testing, Psychometrics, Methodology in Applied Psychology.

De Simone, S., Agus, M., Lasio, D., \& Serri, F. (2018). Development and validation of a measure of work-family interface. Journal of Work and Organizational Psychology, 34(3), 169-179. https://doi.org/10.5093/jwop2018a19

Dex, S., \& Bond, S. (2005). Measuring work-life balance and its covariates. Work, employment and society, 19(3), 627-637. https://doi.org/10.1177/0950017005055676

Eisenberger, R., Huntington, R., Hutchison, S., \& Sowa, D. (1986). Perceived organizational support. Journal of Applied Psychology, 71(3), 500-507. https://doi.org/10.1037/0021-9010.71.3.500

Elo, A.-L., Leppänen, A., \& Jahkola, A. (2003). Validity of a single-item measure of stress symptoms. Scandinavian journal of work, environment \& health, 29(6), 444-451. https://doi.org/10.5271/sjweh.752

Fishbein, M., \& Ajzen, I. (1972). Attitudes and opinions. Annual review of psychology, 23(1), 487544. https://doi.org/10.1146/annurev.ps.23.020172.002415

Frone, M. R., Russell, M., \& Cooper, M. L. (1992). Antecedents and outcomes of work-family conflict: testing a model of the work-family interface. Journal of Applied Psychology, 77(1), 65. https://doi.org/10.1037/0021-9010.77.1.65 
Golden, T. D., Veiga, J. F., \& Dino, R. N. (2008). The impact of professional isolation on teleworker job performance and turnover intentions: does time spent teleworking, interacting face-to-face, or having access to communication-enhancing technology matter? Journal of Applied Psychology, 93(6), 1412. https://doi.org/10.1037/a0012722

Heatherton, T. F., \& Polivy, J. (1991). Development and validation of a scale for measuring state selfesteem. Journal of personality and social psychology, 60(6), 895. https://doi.org/10.1037/0022-3514.60.6.895

John, O. P., \& Srivastava, S. (1999). The Big-Five trait taxonomy: History, measurement, and theoretical perspectives (Vol. 2). University of California Berkeley.

Karasek Jr, R. A. (1979). Job demands, job decision latitude, and mental strain: Implications for job redesign. Administrative science quarterly, 24(2), 285-308. https://doi.org/10.2307/2392498

Karasek, R., Brisson, C., Kawakami, N., Houtman, I., Bongers, P., \& Amick, B. (1998). The Job Content Questionnaire (JCQ): an instrument for internationally comparative assessments of psychosocial job characteristics. Journal of occupational health psychology, 3(4), 322. https://doi.org/10.1037//1076-8998.3.4.322

Kinnunen, U., Feldt, T., Geurts, S., \& Pulkkinen, L. (2006). Types of work-family interface: Wellbeing correlates of negative and positive spillover between work and family. Scandinavian journal of psychology, 47(2), 149-162. https://doi.org/10.1111/j.1467-9450.2006.00502.x

Koopmans, L., Bernaards, C., Hildebrandt, V., van Buuren, S., Van der Beek, A. J., \& de Vet, H. C. (2013). Development of an individual work performance questionnaire. International journal of productivity and performance management, 62(1), 6-28. https://doi.org/10.1108/17410401311285273

Kristensen, H. Hannerz, A. Hogh, \& Borg, V. (2006). The Copenhagen psychosocial questionnaire (COPSOQ). A tool for the assessment and improvement of the psychosocial work environment. Scand. J. Work Environ. Health, 31(6), 438-449. https://doi.org/10.5271/sjweh.948 
Marcus, F., \& Rosenberg, M. (1987). Mattering: its measurement and significance in everyday life [Paper presentation]. Eastern Sociological Society Meetings, Annual meeting of the Eastern Sociological Association, Cincinnati, $\mathrm{OH}$.

Maslach, C., \& Jackson, S. E. (1981). Maslach burnout inventory: research edition; manual. Consulting psychologists press.

Melin, M., Astvik, W., \& Bernhard-Oettel, C. (2014). New work demands in higher education. A study of the relationship between excessive workload, coping strategies and subsequent health among academic staff. Quality in Higher Education, 20(3), 290-308. https://doi.org/10.1080/13538322.2014.979547

Monticone, M., Baiardi, P., Bonetti, F., Ferrari, S., Foti, C., Pillastrini, P., Rocca, B., Vanti, C., \& Zanoli, G. (2012). The Italian version of the Fear-Avoidance Beliefs Questionnaire (FABQ-I): cross-cultural adaptation, factor analysis, reliability, validity, and sensitivity to change. Spine, 37(6), E374-E380. https://doi.org/10.1097/BRS.0b013e31822ff5a7

Muenjohn, N., \& Armstrong, A. (2008). Evaluating the structural validity of the multifactor leadership questionnaire (MLQ), capturing the leadership factors of transformational-transactional leadership. Contemporary management research, 4(1), 3-14. https://doi.org/10.7903/cmr.704

Netemeyer, R. G., Boles, J. S., \& McMurrian, R. (1996). Development and validation of work-family conflict and family-work conflict scales. Journal of Applied Psychology, 81(4), 400-410. https://doi.org/10.1037/0021-9010.81.4.400

Pearce, J. L., \& Gregersen, H. B. (1991). Task interdependence and extrarole behavior: A test of the mediating effects of felt responsibility. Journal of Applied Psychology, 76(6), 838-844. https://doi.org/10.1037/0021-9010.76.6.838

Pluut, H., Ilies, R., Curşeu, P. L., \& Liu, Y. (2018). Social support at work and at home: Dualbuffering effects in the work-family conflict process. Organizational behavior and human decision processes, 146(May), 1-13. https://doi.org/10.1016/j.obhdp.2018.02.001

Ragu-Nathan, T., Tarafdar, M., Ragu-Nathan, B. S., \& Tu, Q. (2008). The consequences of technostress for end users in organizations: Conceptual development and empirical validation. Information Systems Research, 19(4), 417-433. https://doi.org/10.1287/isre.1070.0165 
Rheinberg, F., Vollmeyer, R., \& Engeser, S. (2003). [The assessment of flow experience] Die erfassung des flow-erlebens. In J. Stiensmeier-Pelster \& F. Rheinberg (Eds.), [Diagnosis of Motivation and Self-Concept] In Diagnostik von SelbstkonzeptLernmotivation und Selbstregulation (pp. 262-279). Hogrefe.

Sanchez, J., Callarisa, L., Rodriguez, R. M., \& Moliner, M. A. (2006). Perceived value of the purchase of a tourism product. Tourism management, 27(3), 394-409. https://doi.org/10.1016/j.tourman.2004.11.007

Scandura, T. A., \& Graen, G. B. (1984). Moderating effects of initial leader-member exchange status on the effects of a leadership intervention. Journal of Applied Psychology, 69(3), 428. https://doi.org/10.1037/0021-9010.69.3.428

Schaufeli, W. B., Bakker, A. B., \& Salanova, M. (2006). The measurement of work engagement with a short questionnaire: A cross-national study. Educational and psychological measurement, 66(4), 701-716. https://doi.org/10.1177/0013164405282471

Schaufeli, W. B., Shimazu, A., Hakanen, J., Salanova, M., \& De Witte, H. (2017). An ultra-short measure for work engagement. European Journal of Psychological Assessment, 35(4), 577 591. https://doi.org/10.1027/1015-5759/a000430

Song, Y., \& Gao, J. (2020). Does telework stress employees out? A study on working at home and subjective well-being for wage/salary workers. Journal of Happiness Studies, 21(7), 26492668. https://doi.org/10.1007/s10902-019-00196-6

Sonnentag, S., \& Fritz, C. (2007). The Recovery Experience Questionnaire: development and validation of a measure for assessing recuperation and unwinding from work. Journal of occupational health psychology, 12(3), 204-221. https://doi.org/10.1037/1076-8998.12.3.204

Spector, P. E., Fox, S., Penney, L. M., Bruursema, K., Goh, A., \& Kessler, S. (2006). The dimensionality of counterproductivity: Are all counterproductive behaviors created equal? Journal of vocational behavior, 68(3), 446-460. https://doi.org/10.1016/j.jvb.2005.10.005

Staples, D. S., Hulland, J. S., \& Higgins, C. A. (1999). A self-efficacy theory explanation for the management of remote workers in virtual organizations. Organization Science, 10(6), 758776. https://doi.org/10.1287/orsc. 10.6 .758 
Sweeney, J. C., \& Soutar, G. N. (2001). Consumer perceived value: The development of a multiple item scale. Journal of retailing, 77(2), 203-220. https://doi.org/10.1016/S0022$4359(01) 00041-0$

Taylor, M. F., Brice, J., Buck, N., \& Prentice-Lane, E. (1993). British Household Panel Survey user manual: Volume A: Introduction, technical report and appendices. University of Essex Colchester.

Topp, C. W., Østergaard, S. D., Søndergaard, S., \& Bech, P. (2015). The WHO-5 Well-Being Index: a systematic review of the literature. Psychotherapy and psychosomatics, 84(3), 167-176. https://doi.org/10.1159/000376585

Trougakos, J. P., Beal, D. J., Cheng, B. H., Hideg, I., \& Zweig, D. (2015). Too drained to help: A resource depletion perspective on daily interpersonal citizenship behaviors. Journal of Applied Psychology, 100(1), 227-236. https://doi.org/10.1037/a0038082

Van den Broeck, A., Vansteenkiste, M., De Witte, H., Soenens, B., \& Lens, W. (2010). Capturing autonomy, competence, and relatedness at work: Construction and initial validation of the Work-related Basic Need Satisfaction scale. Journal of occupational and organizational psychology, 83(4), 981-1002. https://doi.org/10.1348/096317909X481382

Warr, P., Cook, J., \& Wall, T. (1979). Scales for the measurement of some work attitudes and aspects of psychological well-being. Journal of occupational Psychology, 52(2), 129-148. https://doi.org/10.1111/j.2044-8325.1979.tb00448.x

Watson, D., Clark, L. A., \& Tellegen, A. (1988). Development and validation of brief measures of positive and negative affect: the PANAS scales. Journal of personality and social psychology, 54(6), 1063. https://doi.org/10.1037//0022-3514.54.6.1063

Zohar, D., Tzischinski, O., \& Epstein, R. (2003). Effects of energy availability on immediate and delayed emotional reactions to work events. Journal of Applied Psychology, 88(6), 1082-1093. https://doi.org/10.1037/0021-9010.88.6.1082 


\section{Supplementary material 3}

Records associated with each dimension

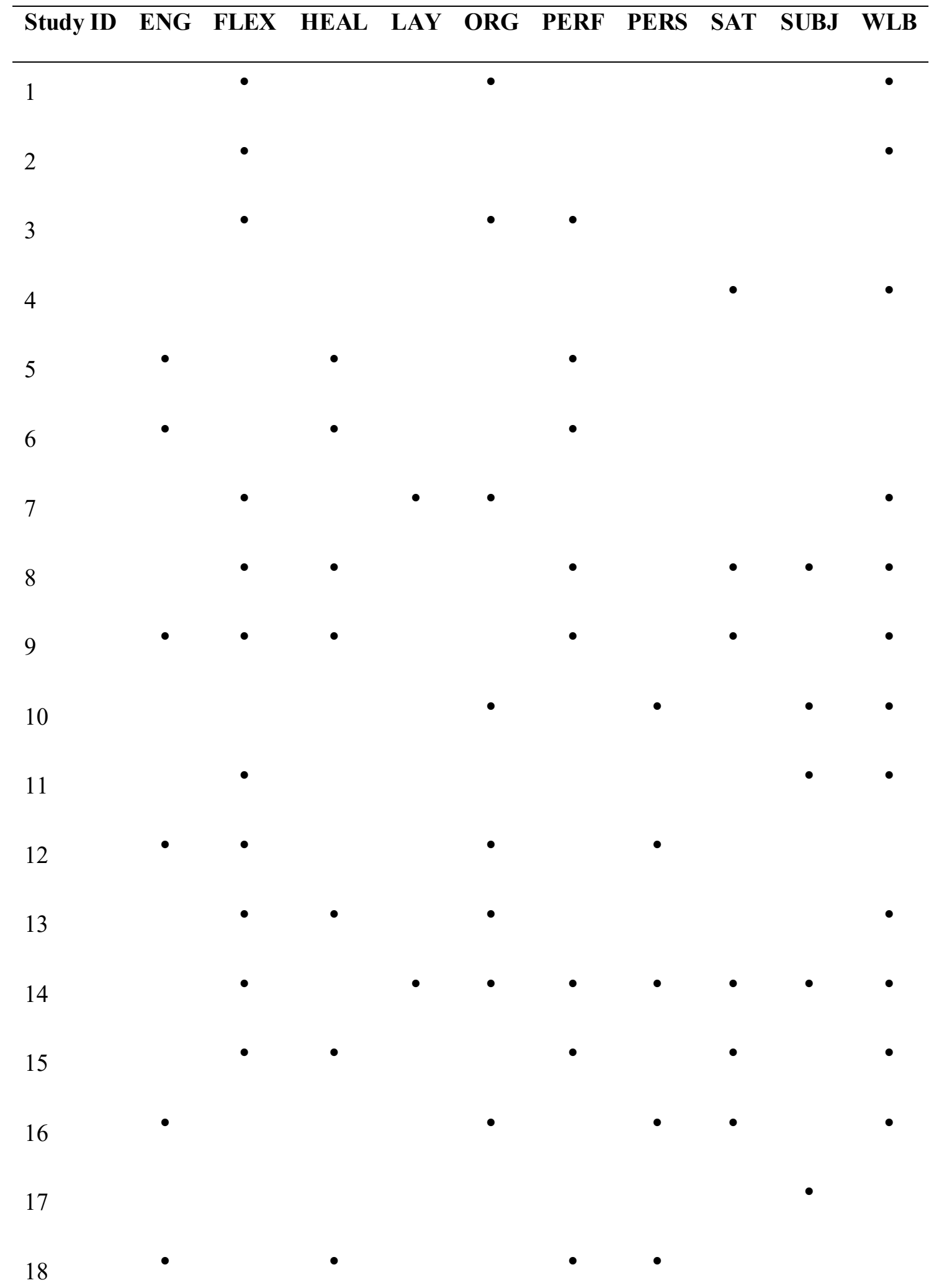


19

20

21

22

23

24

25

26

27

28

29

30

31

32

33

34

$\begin{array}{lllllllllll}\text { Total (\%) } & 38 \% & 56 \% & 47 \% & 18 \% & 32 \% & 35 \% & 26 \% & 38 \% & 26 \% & 62 \%\end{array}$ 